\title{
Long non-coding RNAs as the critical regulators of doxorubicin resistance in tumor cells
}

\author{
Ghazaleh Khalili-Tanha and Meysam Moghbeli* (D)
}

\author{
${ }^{*}$ Correspondence: \\ Meysam_moghbeli@yahoo. \\ com; moghbelim@mums. \\ ac.ir \\ Department of Medical \\ Genetics and Molecular \\ Medicine, School \\ of Medicine, Mashhad \\ University of Medical \\ Sciences, Mashhad, Iran
}

\begin{abstract}
Resistance against conventional chemotherapeutic agents is one of the main reasons for tumor relapse and poor clinical outcomes in cancer patients. Various mechanisms are associated with drug resistance, including drug efflux, cell cycle, DNA repair and apoptosis. Doxorubicin (DOX) is a widely used first-line anti-cancer drug that functions as a DNA topoisomerase II inhibitor. However, DOX resistance has emerged as a large hurdle in efficient tumor therapy. Furthermore, despite its wide clinical application, DOX is a double-edged sword: it can damage normal tissues and affect the quality of patients'lives during and after treatment. It is essential to clarify the molecular basis of DOX resistance to support the development of novel therapeutic modalities with fewer and/or lower-impact side effects in cancer patients. Long non-coding RNAs (IncRNAs) have critical roles in the drug resistance of various tumors. In this review, we summarize the state of knowledge on all the IncRNAs associated with DOX resistance. The majority are involved in promoting DOX resistance. This review paves the way to introducing an IncRNA panel marker for the prediction of the DOX response and clinical outcomes for cancer patients.

Keywords: Doxorubicin, Drug resistance, Cancer, Chemotherapy
\end{abstract}

\section{Background}

Chemotherapy is an effective method of tumor therapy, but some tumors cannot be treated effectively due to multidrug resistance (MDR) [1, 2]. A chemotherapeutic failure of about $85-90 \%$ has been reported for solid tumors [3], making this the main reason for tumor relapse, metastasis and poor clinical outcomes for patients. Various molecular and cellular processes, including membrane transporters, oncogenes, tumor suppressors, DNA repair, apoptosis and epithelial-mesenchymal transition (EMT), are associated with chemoresistance in tumor cells [4]. In addition to this challenge, chemotherapeutic drugs can themselves cause severe side effects in patients, including cardiomyopathy, typhlitis and acute myelotoxicity $[5,6]$.

Doxorubicin (DOX; brand name Adriamycin) is an anthracycline that is widely used as an anticancer agent for various tumors. It inhibits DNA replication and transcription

(C) The Author(s), 2021. Open Access This article is licensed under a Creative Commons Attribution 4.0 International License, which permits use, sharing, adaptation, distribution and reproduction in any medium or format, as long as you give appropriate credit to the original author(s) and the source, provide a link to the Creative Commons licence, and indicate if changes were made. The images or other third party material in this article are included in the article's Creative Commons licence, unless indicated otherwise in a credit line to the material. If material is not included in the article's Creative Commons licence and your intended use is not permitted by statutory regulation or exceeds the permitted use, you will need to obtain permission directly from the copyright holder. To view a copy of this licence, visit http:// creativecommons.org/licenses/by/4.0/. 
by causing DNA damage that prevents mitosis in tumor cells. It also promotes apoptosis by stimulating topoisomerase II to cut DNA strands. However, despite its wide clinical application, DOX is a double-edged sword: it damages normal tissues, thus negatively affecting the quality of patients' lives during and after treatment. It has toxic effects on normal heart, brain, kidney and liver tissues [7].

Clarifying the molecular basis of DOX resistance could enable the development and introduction of novel therapeutic modalities with fewer and/or lower-impact side effects in cancer patients. Various genetic mutation and epigenetic mechanisms can be related with DOX resistance. Mutations in $\mathrm{ABC}$ transporter family members such as $\mathrm{ABCB} 1$ [8], ABCBG2 [9] and MRP1 [10], as well as DNA repair factors such as p53 [11-14] are considered to be the major causes of DOX resistance. There is also evidence for a role of epigenetic aberration in chemoresistance [15-17].

Long non-coding RNAs (lncRNAs) are involved in various cellular processes via transcriptional regulation of their target genes. They can also function as oncogenes or tumor suppressors $[18,19]$. Based on their biogenesis, lncRNAs are categorized as intergenic, antisense, intronic, overlapping or full lapping [18]. Antisense (AS) lncRNAs are the largest category, making up about 70\% of the long non-coding transcriptome [20].

LncRNAs have important effects on tumorigenesis through their modulation of various pathophysiological processes, including the stability of mRNA, RNA splicing, chromatin remodeling and miRNA sponging (Fig. 1) [21-26]. Their deregulation is one of the main obstacles for the effectiveness of chemotherapy [27-29]. They are involved in chemotherapeutic responses through their regulation of histone modification and DNA methylation. Since epigenetic signatures are inheritable and reversible, they have been suggested as effective biomarkers for the prediction of chemotherapeutic outcomes [29]. This review summarizes the molecular mechanisms whereby lncRNAs affect DOX responses in tumor cells (Fig. 2, Table 1).

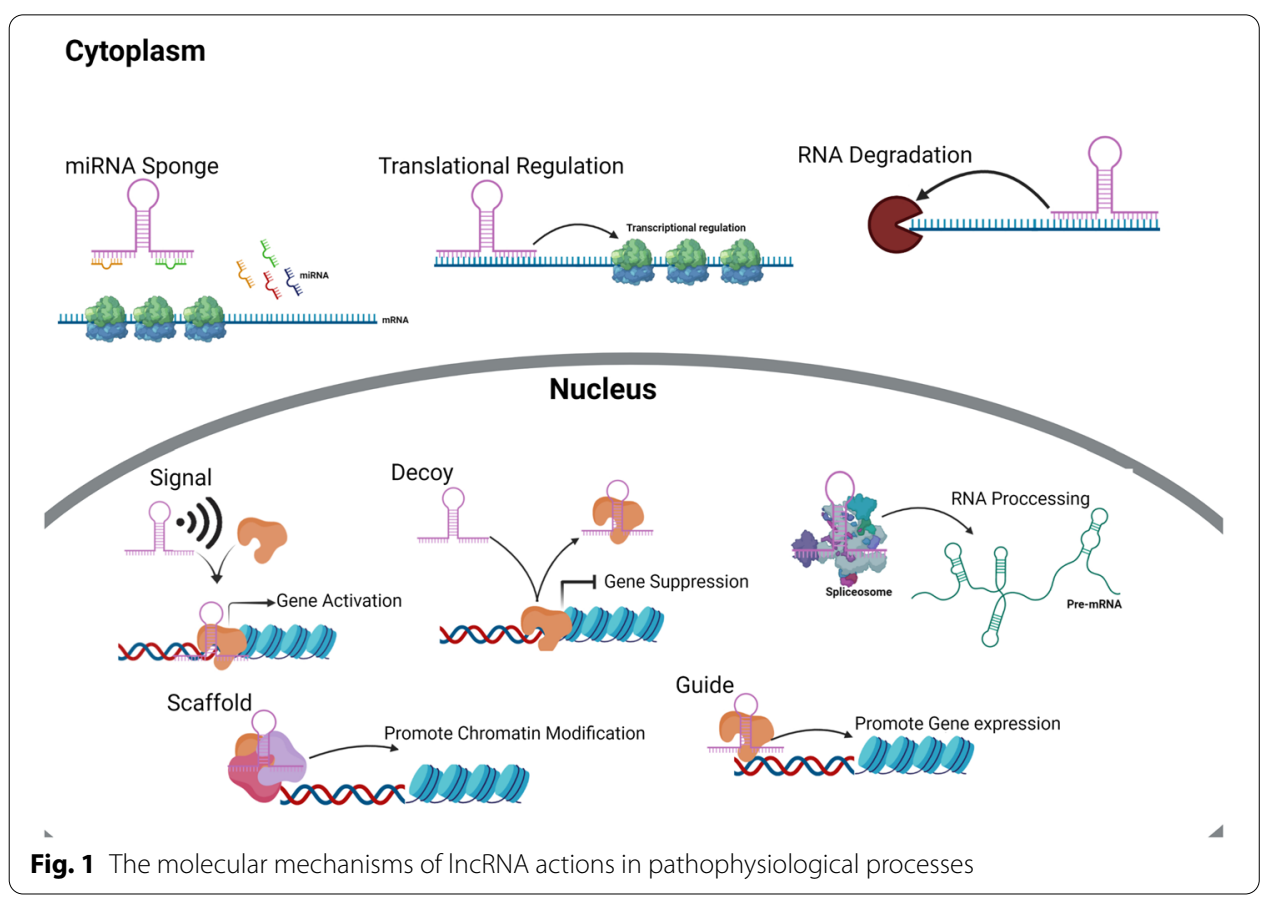




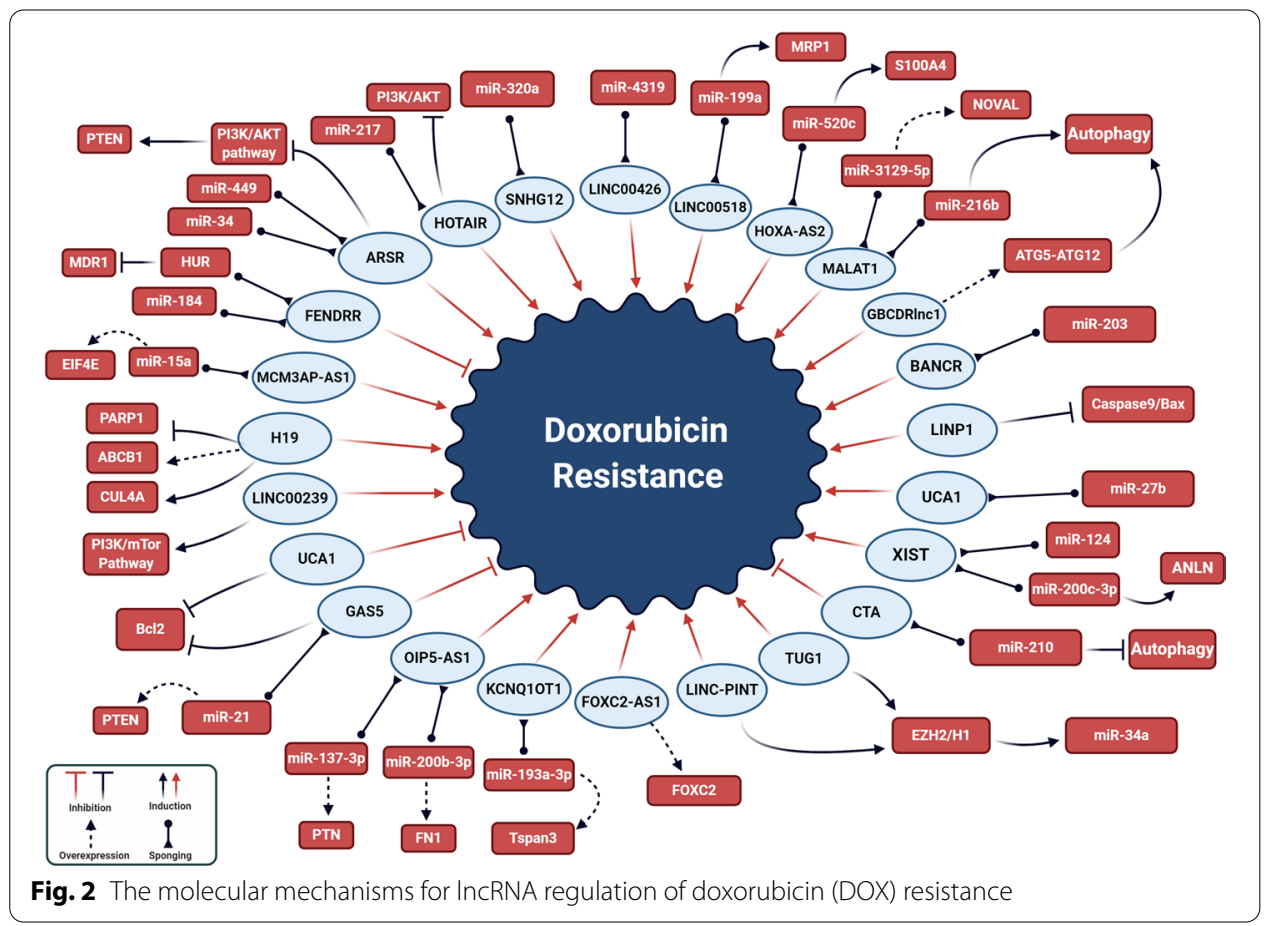

\section{Breast cancer}

Various screening and therapeutic methods have been used against breast cancer [30], but in advanced stages, many patients still develop invasive carcinoma and have poor prognosis [31]. Although Doxorubicin is one of the most efficient drugs for breast cancer treatment, drug resistance can be observed after several treatments [32]. About 30\% of breast cancer patients who receive chemotherapy experienced the poor prognosis that is associated with the expression of multidrug resistance proteins [33].

It has been reported that XIST increases tumor cells proliferation and suppresses apoptosis in DOX-treated MDA-MB-231 cells through upregulation of the anillin actinbinding protein (ANLN). XIST was suggested to be a competitive endogenous RNA that increases the levels of ANLN expression via miR-200c-3p targeting [34].

Linc00152 is a critical factor during the progression of various cancers, including lung, liver, and colorectal cancer (CRC) [35-37]. Mitosis and the cell cycle could be modulated by Linc00152 in Hela cells [38]. During EMT, epithelial tumor cells gain mesenchymal properties through reduced adhesion and increased motility. This process is involved in early stages of tumor metastasis [39, 40]. Linc00152 upregulation has been reported in breast cancer tissues and cell lines, where it increased the levels of cell growth, migration, EMT and DOX-resistance [41].

Multidrug resistance protein 1 (MRP1) is a member of the ATP-binding cassette (ABC) C superfamily, which is involved in MDR of different tumors [42, 43]. Increased linc00518 and MRP1 expression levels have been reported in breast cancer tissue and cell lines. Higher expressions of linc00518 and MRP1 were also observed in MDR breast tumor cells (MCF-7/DOX) in comparison with parental cells (MCF-7). Drug resistance could be improved through regulation of the miR-199a/MRP1 axis in breast cancer tissue. Linc00518 upregulated the MRP1 via MiR-199a sponging. The resistance of the 
Table 1 All of the long non-coding RNAs associated with Doxorubicin response in different cancers

\begin{tabular}{|c|c|c|c|c|c|c|}
\hline Cancer type & DOX response & LncRNA & Target & Samples & Function & References \\
\hline \multicolumn{7}{|c|}{ Breast cancer (BC) } \\
\hline$B C$ & Resistance & XIST & $\begin{array}{l}\text { miR-200c-3p / } \\
\text { ANLN }\end{array}$ & $\begin{array}{l}\text { MDA-MB-231/ } \\
\text { ADM and } \\
\text { MDA-MB-231 } \\
\text { cell lines }\end{array}$ & $\begin{array}{l}\text { XIST up regu- } \\
\text { lated ANLN } \\
\text { by sponging } \\
\text { miR-200c-3p } \\
\text { and inhibited } \\
\text { cell prolifera- } \\
\text { tion as well } \\
\text { as promoted } \\
\text { apoptosis }\end{array}$ & [34] \\
\hline$B C$ & Resistance & Linc00152 & - & $\begin{array}{l}40 \mathrm{NT}^{*} \\
\text { MDA-MB-231 } \\
\text { and MCF-7 } \\
\text { cell lines }\end{array}$ & $\begin{array}{l}\text { Knockdown } \\
\text { of Linc00152 } \\
\text { suppressed } \\
\text { tumor } \\
\text { growth, cell } \\
\text { migration, } \\
\text { invasion, and } \\
\text { chemo- } \\
\text { resistance }\end{array}$ & [41] \\
\hline$B C$ & Resistance & Linc00518 & miR-199a/MRP1 & $\begin{array}{l}30 \text { NT } \\
\text { MCF-10A, } \\
\text { MCF-7/ADR } \\
\text { and MCF-7 } \\
\text { cell lines }\end{array}$ & $\begin{array}{l}\text { Linc00518 } \\
\text { Knockdown } \\
\text { suppressed } \\
\text { MRP1 expres- } \\
\text { sion and } \\
\text { induced cell } \\
\text { apoptosis }\end{array}$ & [44] \\
\hline$B C$ & Resistance & HOTAIR & PI3K/AKT & $\begin{array}{l}\text { MCF-7 and } \\
\text { DOXR-MCF-7 } \\
\text { cell lines }\end{array}$ & $\begin{array}{l}\text { HOTAIR sup- } \\
\text { pressed PI3K } \\
\text { AKT pathway, } \\
\text { reduced cell } \\
\text { survival and } \\
\text { promoted } \\
\text { apoptosis }\end{array}$ & [48] \\
\hline$B C$ & Resistance & Linc00668 & SND1 & $\begin{array}{l}\text { HMEC-hTERT, } \\
\text { MCF-10A, } \\
\text { MCF-7, T47D, } \\
\text { MDA-MB-231, } \\
\text { HS578t, } \\
\text { and 293T, } \\
\text { SUM149, and } \\
\text { SUM159 cell } \\
\text { lines }\end{array}$ & $\begin{array}{l}\text { Linc00668 inter- } \\
\text { acted with } \\
\text { SND1 and } \\
\text { regulated } \\
\text { SMAD2/3/4 } \\
\text { expression, } \\
\text { and also } \\
\text { decreased } \\
\text { invasion, } \\
\text { self-renewal, } \\
\text { and chemo- } \\
\text { resistance }\end{array}$ & [54] \\
\hline$B C$ & Resistance & DCST1-AS1 & ANXA1 & $\begin{array}{l}\text { MDA-MB-231, } \\
\text { BT-549, T-47D, } \\
\text { and MCF7 cell } \\
\text { lines }\end{array}$ & $\begin{array}{l}\text { DCST1-AS1 tar- } \\
\text { geted ANXA1 } \\
\text { and induced } \\
\text { EMT }\end{array}$ & {$[61]$} \\
\hline$B C$ & Resistance & LINC00160 & $C / E B P \beta / T F F 3$ & $\begin{array}{l}47 \text { NT } \\
\text { MCF-7, MCF-7/ } \\
\text { Tax, BT474, } \\
\text { BT474/Dox } \\
\text { and MCF10A } \\
\text { cell lines }\end{array}$ & $\begin{array}{l}\text { LINC00160 } \\
\text { knockdown } \\
\text { reduced cell } \\
\text { migration } \\
\text { and invasion }\end{array}$ & {$[64]$} \\
\hline
\end{tabular}


Table 1 (continued)

\begin{tabular}{|c|c|c|c|c|c|c|}
\hline Cancer type & DOX response & LncRNA & Target & Samples & Function & References \\
\hline$B C$ & Resistance & LINP1 & CASP9/BAX & $\begin{array}{l}\text { MDA-MB-231, } \\
\text { MDA-MB- } \\
\text { 231/5FU, } \\
\text { MDA-MB-231/ } \\
\text { DOX, MDA- } \\
\text { MB-468 and } \\
\text { MCF7 cell } \\
\text { lines }\end{array}$ & $\begin{array}{l}\text { LINP1 } \\
\text { knockdown } \\
\text { suppressed } \\
\text { tumor } \\
\text { growth and } \\
\text { metastasis } \\
\text { as well as } \\
\text { promoted } \\
\text { apoptosis }\end{array}$ & [65] \\
\hline$B C$ & Resistance & H19 & $\begin{array}{l}\text { CUL4A/ABCB1/ } \\
\text { MDR1 }\end{array}$ & MCF-7 cell lines & $\begin{array}{l}\text { H19 up regu- } \\
\text { lated CUL4A } \\
\text { and ABCB1/ } \\
\text { MDR1 genes }\end{array}$ & [69] \\
\hline$B C$ & Resistance & H19 & PARP-1 & $\begin{array}{l}63 \mathrm{NT} \\
\text { MCF-7 and } \\
\text { MCF-7/Dox } \\
\text { cell lines }\end{array}$ & $\begin{array}{l}\text { Knockdown of } \\
\text { H19 increased } \\
\text { PARP-1 } \\
\text { expression } \\
\text { and induced } \\
\text { cell death }\end{array}$ & [71] \\
\hline \multicolumn{7}{|c|}{ Osteosarcoma (OS) } \\
\hline OS & Resistance & TUG1 & $A K T$ & $\begin{array}{l}\text { Saos- } 2 \text { and } \\
\text { MG-63 cell } \\
\text { line }\end{array}$ & $\begin{array}{l}\text { Polydatin } \\
\text { inhibited } \\
\text { TUG1/AKT } \\
\text { axis and pro- } \\
\text { liferation and } \\
\text { promoted } \\
\text { apoptosis }\end{array}$ & [83] \\
\hline OS & Resistance & FOXC2-AS1 & FOXC2 & $\begin{array}{l}68 \text { NT } \\
\text { MG63, SaoS2 } \\
\text { and HOS cell } \\
\text { lines }\end{array}$ & $\begin{array}{l}\text { FOXC2-AS1 } \\
\text { facilities } \\
A B C B 1 \\
\text { expression } \\
\text { by increas- } \\
\text { ing FOXC2 } \\
\text { expression }\end{array}$ & [86] \\
\hline OS & Resistance & FOXC2-AS1 & $A B C B 1$ & $\begin{array}{c}\text { MG63, SaoS2 } \\
\text { and U-2OS } \\
\text { cell lines }\end{array}$ & $\begin{array}{l}\text { Silencing of } \\
\text { FOXC2-AS1 } \\
\text { and ABCB1 } \\
\text { repressed } \\
\text { tumor } \\
\text { growth }\end{array}$ & [89] \\
\hline OS & Resistance & OIP5-ASI & $\operatorname{miR}-137-3 p$ & $\begin{array}{l}56 \text { tumor } \\
\text { tissues and } \\
16 \text { normal } \\
\text { tissues } \\
\text { hFOB1.19, } \\
\text { MG63, and } \\
\text { MG63/DOX } \\
\text { cell lines }\end{array}$ & $\begin{array}{l}\text { OIP5-AS1 } \\
\text { knockdown } \\
\text { inhibited pro- } \\
\text { liferation and } \\
\text { metastasis }\end{array}$ & [93] \\
\hline OS & Resistance & OIP5-AS1 & miR-200b-3p & $\begin{array}{l}80 \text { patients } \\
\text { MG63, KHOS } \\
\text { and U2OS cell } \\
\text { lines }\end{array}$ & $\begin{array}{l}\text { OIP5-AS1 } \\
\text { sponged } \\
\text { miR-200b-3p } \\
\text { and regu- } \\
\text { lated FN1 } \\
\text { expression. } \\
\text { Overexpres- } \\
\text { sion of FN1 } \\
\text { contributed } \\
\text { to the } \\
\text { sensitivity of } \\
\text { OS cells to } \\
\text { doxorubicin }\end{array}$ & [97] \\
\hline
\end{tabular}


Table 1 (continued)

\begin{tabular}{|c|c|c|c|c|c|c|}
\hline Cancer type & DOX response & LncRNA & Target & Samples & Function & References \\
\hline OS & Resistance & SNHG12 & $\begin{array}{l}\text { miR-320al } \\
\text { MCL1 }\end{array}$ & $\begin{array}{l}32 \text { doxorubicin- } \\
\text { resistant } \\
\text { patients and } \\
32 \text { doxoru- } \\
\text { bicin-sensitive } \\
\text { patients } \\
\text { MG-63, U2OS, } \\
\text { HOS, SAOS-2 } \\
\text { and hFOB cell } \\
\text { lines }\end{array}$ & $\begin{array}{l}\text { SNHG12 modu- } \\
\text { lated Wnt/ß- } \\
\text { catenin } \\
\text { pathway, } \\
\text { so inhibited } \\
\text { miR-320a } \\
\text { expression } \\
\text { and pro- } \\
\text { moted MCL1 } \\
\text { expression }\end{array}$ & [103] \\
\hline OS & Resistance & LINC00426 & $\operatorname{miR}-4319$ & $\begin{array}{l}\text { MG63, KHOS, } \\
\text { U2OS, MG63/ } \\
\text { DXR, and } \\
\text { KHOS/DXR } \\
\text { cell lines }\end{array}$ & $\begin{array}{l}\text { Knockdown of } \\
\text { LINC00426 } \\
\text { significantly } \\
\text { decreased } \\
\text { cell viability } \\
\text { and prolifera- } \\
\text { tion }\end{array}$ & [104] \\
\hline OS & Sensitivity & CTA & $\operatorname{miR}-210$ & $\begin{array}{l}30 \text { patients } \\
\text { Saos-2, U-2OS, } \\
\text { MG-63 and } \\
\text { MG-63/DOX } \\
\text { cell lines }\end{array}$ & $\begin{array}{l}\text { Overexpres- } \\
\text { sion of CTA } \\
\text { reduced } \\
\text { autophagy } \\
\text { and } \\
\text { promoted } \\
\text { apoptosis }\end{array}$ & [105] \\
\hline OS & Sensitivity & FENDRR & $A B C B 1 / A B C C 1$ & $\begin{array}{l}80 \text { patients } \\
\text { MG63, SaoS2, } \\
\text { HOS and } \\
\text { MG63/DXR } \\
\text { cell lines }\end{array}$ & $\begin{array}{l}\text { FENDRR down } \\
\text { regulated } \\
\text { ABCB1 and } \\
\text { ABCC1 as } \\
\text { well as sup- } \\
\text { pressed DOX } \\
\text { resistance } \\
\text { and induced } \\
\text { cells apop- } \\
\text { tosis }\end{array}$ & [108] \\
\hline \multicolumn{7}{|c|}{ Gastric cancer (GC) } \\
\hline GC & Resistance & HOTAIR & $\operatorname{miR}-217$ & $\begin{array}{l}30 \text { NT } \\
\text { BGC-823, SGC- } \\
7901, \text { KATO-3, } \\
\text { MGC-803, and } \\
\text { GES1 }\end{array}$ & $\begin{array}{l}\text { Knockdown } \\
\text { of HOTAIR } \\
\text { inhibited cell } \\
\text { proliferation } \\
\text { and migra- } \\
\text { tion }\end{array}$ & [116] \\
\hline GC & Sensitivity & UCA1 & PARP & $\begin{array}{l}77 \text { NT } \\
\text { GES-1, BGC-823 } \\
\text { and SGC7901 } \\
\text { cell lines }\end{array}$ & $\begin{array}{l}\text { Knockdown of } \\
\text { UCA1 caused } \\
\text { repression of } \\
\text { proliferation } \\
\text { in cancerous } \\
\text { cells }\end{array}$ & [120] \\
\hline GC & Resistance & UCA1 & $\operatorname{miR}-27 b$ & $\begin{array}{l}28 \text { patients } \\
\text { SGC-7901, SGC- } \\
\text { 7901/ADR, } \\
\text { SGC-7901/ } \\
\text { DDP and } \\
\text { SGC-7901/FU }\end{array}$ & $\begin{array}{l}\text { Knockdown } \\
\text { of UCA1 } \\
\text { induced the } \\
\text { expression } \\
\text { of miR-27b, } \\
\text { resulting in } \\
\text { reduction of } \\
\text { Bcl2 expres- } \\
\text { sion and } \\
\text { promotion } \\
\text { of CASP3 } \\
\text { expression }\end{array}$ & [123] \\
\hline
\end{tabular}


Table 1 (continued)

\begin{tabular}{|c|c|c|c|c|c|c|}
\hline Cancer type & DOX response & LncRNA & Target & Samples & Function & References \\
\hline GC & Resistance & D63785 & $\operatorname{miR}-422 a$ & $\begin{array}{l}21 \text { patients } \\
\text { GES-1, } \\
\text { SGC7901, } \\
\text { MGC803, } \\
\text { BGC823, NCl- } \\
\text { N87, HEK293 } \\
\text { and HEK293T } \\
\text { cell lines }\end{array}$ & $\begin{array}{l}\text { Reduced } \\
\text { IncR-D63785 } \\
\text { expression } \\
\text { repressed } \\
\text { proliferation, } \\
\text { invasion, and } \\
\text { metastasis }\end{array}$ & [128] \\
\hline GC & Resistance & NEAT1 & - & $\begin{array}{l}76 \text { NT } \\
\text { SGC790, GES-1, } \\
\text { SGC7901/ } \\
\text { ADR cell lines }\end{array}$ & $\begin{array}{l}\text { NEAT1 } \\
\text { repressed cell } \\
\text { proliferation, } \\
\text { apoptosis, } \\
\text { and invasion }\end{array}$ & [131] \\
\hline GC & Resistance & MRUL & $P-g p$ & $\begin{array}{l}\text { SGC7901/ADR, } \\
\text { SGC7901/ } \\
\text { VCR, } \\
\text { SGC7901/ } \\
\text { ADR, and } \\
\text { SGC7901 cell } \\
\text { lines }\end{array}$ & $\begin{array}{l}\text { MRUL deple- } \\
\text { tion induced } \\
\text { apoptosis }\end{array}$ & [132] \\
\hline \multicolumn{7}{|c|}{ Leukemia and lymphoma } \\
\hline AML & Resistance & KCNQ10T1 & $\begin{array}{l}\text { miR-193a3p/ } \\
\text { Tspan3 }\end{array}$ & $\begin{array}{l}74 \text { patients and } \\
37 \text { healthy } \\
\text { subjects } \\
\text { HS-5, HL60, } \\
\text { HL60/ADR, } \\
\text { K562, and } \\
\text { K562/ADR cell } \\
\text { lines }\end{array}$ & $\begin{array}{l}\text { KCNQ1OT1 } \\
\text { knockdown } \\
\text { suppressed } \\
\text { the cell pro- } \\
\text { liferation and } \\
\text { invasion }\end{array}$ & [139] \\
\hline AML & Resistance & TUG1 & $\operatorname{miR}-34 a$ & $\begin{array}{l}36 \text { patients and } \\
23 \text { healthy } \\
\text { subject } \\
\text { HS-5, HL60, and } \\
\text { HL60/ADR }\end{array}$ & $\begin{array}{l}\text { TUG1 knock- } \\
\text { down over- } \\
\text { came ADR } \\
\text { resistance } \\
\text { of AML by } \\
\text { epigenetically } \\
\text { enhancing } \\
\text { miR-34a } \\
\text { expression }\end{array}$ & [141] \\
\hline AML & Resistance & HOXA-AS2 & $\begin{array}{l}\text { miR-520c-3p / } \\
\text { S100A4 }\end{array}$ & $\begin{array}{l}48 \text { patients } \\
\text { U937, U937/ } \\
\text { ADR, THP-1, } \\
\text { and THP-1/ } \\
\text { ADR cell lines }\end{array}$ & $\begin{array}{l}\text { HOXA-AS2 } \\
\text { acted as } \\
\text { ceRNA of } \\
\text { miR-520c-3p } \\
\text { and induced } \\
\text { S100A4 } \\
\text { expression. } \\
\text { Knockdown } \\
\text { of HOXA-AS2 } \\
\text { expression } \\
\text { significantly } \\
\text { suppressed } \\
\text { cell prolifera- } \\
\text { tion }\end{array}$ & [144] \\
\hline AML & Resistance & Linc00239 & PIBK/ATK/MTOR & $\begin{array}{l}\text { HL-60 and KG-1 } \\
\text { cell lines }\end{array}$ & $\begin{array}{l}\text { Linc00239 acti- } \\
\text { vated PI3K/ } \\
\text { ATK/mTOR } \\
\text { pathway. } \\
\text { Linc00239 } \\
\text { knockdown } \\
\text { suppressed } \\
\text { the cell pro- } \\
\text { liferation and } \\
\text { migration }\end{array}$ & [147] \\
\hline
\end{tabular}


Table 1 (continued)

\begin{tabular}{|c|c|c|c|c|c|c|}
\hline Cancer type & DOX response & LncRNA & Target & Samples & Function & References \\
\hline CML & Sensitivity & FENDRR & HuR & $\begin{array}{l}\text { K562 and KCL22 } \\
\text { cell lines }\end{array}$ & $\begin{array}{l}\text { FENDER over- } \\
\text { expression } \\
\text { promoted } \\
\text { cell apoptosis } \\
\text { and sup- } \\
\text { pressed cell } \\
\text { proliferation }\end{array}$ & {$[155]$} \\
\hline $\mathrm{BL}$ & Resistance & MCM3AP-AS1 & miR-15a/EIF4E & $\begin{array}{l}41 \text { patients } \\
\text { B-NHL cell line }\end{array}$ & $\begin{array}{l}\text { MCM3AP-AS1 } \\
\text { knockdown } \\
\text { decreased } \\
\text { cell viability } \\
\text { and increased } \\
\text { apoptosis }\end{array}$ & [160] \\
\hline \multicolumn{7}{|c|}{ Hepatocellular carcinoma (HCC) } \\
\hline $\mathrm{HCC}$ & Resistance & MALAT1 & $\operatorname{miR}-216 b$ & $\begin{array}{l}\text { BEL-7402 } \\
\text { and BEL- } \\
\text { 7402/5-FU } \\
\text { cell lines }\end{array}$ & $\begin{array}{l}\text { MALAT1 } \\
\text { knockdown } \\
\text { decreased } \\
\text { proliferation } \\
\text { and migra- } \\
\text { tion }\end{array}$ & [169] \\
\hline $\mathrm{HCC}$ & Resistance & InCARSR & $\begin{array}{l}\text { miR-34/miR- } \\
\text { 449/PTEN }\end{array}$ & $\begin{array}{l}92 \text { NT } \\
\text { SMMC-7721 } \\
\text { and HepG2 } \\
\text { cell lines }\end{array}$ & $\begin{array}{l}\text { IncARSR pro- } \\
\text { moted PTEN } \\
\text { mRNA deg- } \\
\text { radation and } \\
\text { modulated } \\
\text { PTEN-PI3K } \\
\text { Akt pathway }\end{array}$ & {$[177]$} \\
\hline $\mathrm{HCC}$ & Resistance & MALAT1 & $\begin{array}{l}\text { miR-3129-5p/ } \\
\text { Noval }\end{array}$ & $\begin{array}{l}36 \text { patients } \\
\text { Huh-7 and } \\
\text { Hep3B cell } \\
\text { lines }\end{array}$ & $\begin{array}{l}\text { MALAT1 } \\
\text { knockdown } \\
\text { suppressed } \\
\text { proliferation, } \\
\text { migration, } \\
\text { invasion, and } \\
\text { promoted } \\
\text { apoptosis }\end{array}$ & [174] \\
\hline $\mathrm{HCC}$ & Resistance & NEAT1 & - & $\begin{array}{l}\text { HepG2, PLC/ } \\
\text { PRF/5, and } \\
\text { Huh7 cell } \\
\text { lines }\end{array}$ & $\begin{array}{l}\text { NEAT1 up } \\
\text { regulation in } \\
\text { DOX resistant } \\
\text { HCC cells }\end{array}$ & {$[175]$} \\
\hline $\mathrm{HCC}$ & Sensitivity & GAS5 & miR-21/PTEN & $\begin{array}{l}\text { HepG2 and } \\
\text { HepB3 cell } \\
\text { lines }\end{array}$ & $\begin{array}{l}\text { GAS5 regulated } \\
\text { PTEN expres- } \\
\text { sion through } \\
\text { binding to } \\
\text { miR- } 21 \text { and } \\
\text { reduced cell } \\
\text { proliferation }\end{array}$ & [178] \\
\hline $\mathrm{HCC}$ & Sensitivity & H19 & - & $32 \mathrm{NT}$ & $\begin{array}{l}\text { H19 inhibited } \\
\text { HCC cell } \\
\text { proliferation } \\
\text { following the } \\
\text { doxorubicin } \\
\text { treatments }\end{array}$ & {$[179]$} \\
\hline \multicolumn{7}{|c|}{ Colorectal cancer (CRC) } \\
\hline CRC & Resistance & XIST & $\operatorname{miR}-124$ & $\begin{array}{l}31 \text { patients } \\
\text { HCT116 and } \\
\text { LoVo cell lines }\end{array}$ & $\begin{array}{l}\text { XIST inhibited } \\
\text { miR-124 } \\
\text { expression } \\
\text { through } \\
\text { spong- } \\
\text { ing. XIST } \\
\text { knockdown } \\
\text { enhanced the } \\
\text { anti-tumor } \\
\text { effect of DOX }\end{array}$ & [187] \\
\hline
\end{tabular}


Table 1 (continued)

\begin{tabular}{|c|c|c|c|c|c|c|}
\hline Cancer type & DOX response & LncRNA & Target & Samples & Function & References \\
\hline CRC & Resistance & BANCR & miR-203 & $\begin{array}{l}32 \text { NT } \\
\text { HCT116, LoVo, } \\
\text { NCM460 and } \\
\text { HEK293T cell } \\
\text { lines }\end{array}$ & $\begin{array}{l}\text { BANCR } \\
\text { knockdown } \\
\text { suppressed } \\
\text { tumor } \\
\text { growth }\end{array}$ & [191] \\
\hline CRC & Resistance & GASS & NODAL & HCT116 cell line & $\begin{array}{l}\text { GASS knock- } \\
\text { down } \\
\text { suppressed } \\
\text { proliferation } \\
\text { of cancer } \\
\text { stem cells }\end{array}$ & [194] \\
\hline \multicolumn{7}{|c|}{ Thyroid and gallbladder cancers } \\
\hline ATC & Sensitivity & PTCSC3 & STAT3/INO80 & $\begin{array}{l}20 \text { FTC tissues } \\
\text { and } 20 \text { ATC } \\
\text { tissues } \\
\text { 8505C, FTC 238, } \\
\text { and FTC 133 } \\
\text { cell lines }\end{array}$ & $\begin{array}{l}\text { PTCSC3 } \\
\text { regulated } \\
\text { STAT3/ INO80 } \\
\text { pathway and } \\
\text { inhibited } \\
\text { drug resist- } \\
\text { ance }\end{array}$ & [203] \\
\hline GBC & Resistance & GBCDR/nc1 & ATG5-ATG12 & $\begin{array}{l}45 \mathrm{NT} \\
\mathrm{NOZ} \text { and GBC- } \\
\text { SD cell lines }\end{array}$ & $\begin{array}{l}\text { GBCDR/nc1 } \\
\text { knockdown } \\
\text { inhibited } \\
\text { autophagy }\end{array}$ & {$[205]$} \\
\hline \multicolumn{7}{|c|}{ Prostate and urothelial cancers } \\
\hline RCC & Resistance & LINC-PINT & $E Z H 1 / E Z H 2$ & $\begin{array}{l}98 \text { tumor } \\
\text { tissues and } \\
16 \text { healthy } \\
\text { tissues } \\
\text { HKC, 786-O, } \\
\text { A498, 769P, } \\
\text { Caki-2, Caki- } \\
\text { 1, ACHN, } \\
\text { OS-RC-2, and } \\
\text { SN12-PM6 } \\
\text { cell lines }\end{array}$ & $\begin{array}{l}\text { LINC-PINT } \\
\text { knockdown } \\
\text { decreased } \\
\text { proliferation, } \\
\text { cell progres- } \\
\text { sion, and } \\
\text { promoted } \\
\text { apoptosis }\end{array}$ & {$[208]$} \\
\hline $\mathrm{BCa}$ & Sensitivity & GAS5 & $B C L 2$ & $\begin{array}{l}82 \text { tumor } \\
\text { tissues and } \\
37 \text { healthy } \\
\text { tissues } \\
\text { BTCC T24, J82, } \\
\text { CCC-HB-2, } \\
\text { and T24/DOX } \\
\text { cell lines }\end{array}$ & $\begin{array}{l}\text { GAS5 } \\
\text { knockdown } \\
\text { increased } \\
\text { BCL2 expres- } \\
\text { sion and } \\
\text { apoptosis }\end{array}$ & [212] \\
\hline TCC & Resistance & HOTAIR & - & $\begin{array}{l}35 \text { TCC tissues } \\
\text { and } 16 \\
\text { healthy tis- } \\
\text { sues } \\
\text { TCC T24, J82, } \\
\text { and SV-HUC-1 } \\
\text { cell lines }\end{array}$ & $\begin{array}{l}\text { HOTAIR } \\
\text { knockdown } \\
\text { inhibited } \\
\text { cell prolif- } \\
\text { eration and } \\
\text { promoted } \\
\text { apoptosis }\end{array}$ & [213] \\
\hline PCA & Resistance & LOXL1-AS1 & miR-let-7a-5p & $\begin{array}{l}\text { DU-145 and } \\
\text { DU-145/DOX } \\
\text { cell lines }\end{array}$ & $\begin{array}{l}\text { LOXL1-AS1 } \\
\text { knockdown } \\
\text { inhibited cell } \\
\text { proliferation } \\
\text { and migra- } \\
\text { tion as well } \\
\text { as promoted } \\
\text { apoptosis }\end{array}$ & {$[219]$} \\
\hline
\end{tabular}


MCF-7/DOX cell line was also increased toward DOX, VCR, and PTX treatments via the miR-199a/MRP1 axis [44].

AKT is a Ser/Thr kinase involved in cell proliferation, apoptosis, and migration. It inhibits BAD pro-apoptotic factor via phosphorylation, which results in disassembly from $\mathrm{BCL}-2 / \mathrm{BCL}-\mathrm{X}$. AKT also upregulates the pro-survival genes via NF- $\mathrm{kB}$ activation. There are significant correlations between increased levels of AKT1 expression and resistance toward paclitaxel [45]. The PI3K/AKT/mTOR pathway has a pivotal regulatory role in the cell cycle, cell proliferation, metabolism, and protein synthesis $[46$, 47]. It has been reported that HOTAIR promoted DOX sensitivity via repression of the PI3K/AKT/mTOR axis. Inhibition of HOTAIR markedly decreased the expression of MDR proteins, which resulted in reduced cell survival and the promotion of apoptosis in DOXR-MCF-7 cells. Moreover, the CASP3, BCL-2, and BAX expression levels were significantly altered following HOTAIR inhibition, which increased apoptosis in DOXRMCF-7 cells [48].

Breast cancer stem cells are a sub-population of tumor cells that have the ability of self-renewal, EMT, and chemoresistance [49]. Since SND1 is able to bind with other proteins and nucleic acids, it can regulate various proteins, including transcription factors and co-regulatory factors [50]. STAT6, STAT5, and c-MYB are SND1-associated cofactor proteins [51]. SND1 is also involved in splicing through its Tudor-SN domain [52], and mRNA stabilization through staphylococcal nuclease-like domains [53]. It has been reported that there is a correlation between linc00668 upregulation and lymph node metastasis in BC patients. Linc00668 induces cell invasion, self-renewal properties, and DOX resistance in BC cells through SND1 binding to upregulate SMAD2/3/4 [54].

The most significant signs of the EMT process are vimentin upregulation and E-cadherin downregulation [55]. There is a negative correlation between the E-cadherin expression and tumor progression in breast cancer patients [56]. EMT progression is regulated by SNAI1, which is an EMT-specific transcription factor that represses E-cadherin expression and promotes tumor invasion [57]. Vimentin is a type III intermediate filament produced by fibroblasts and endothelial cells. Tumor invasion can be decreased through vimentin downregulation as a consequence of re-epithelialized cells [58]. Annexin A1 (ANXA1) is in the calcium-dependent phospholipid-binding protein family involved in anti-inflammation [59]. It has also pivotal roles in the regulation of cell proliferation, adhesion, and metastasis [60]. The canonical TGF- $\beta$ signaling pathway modulates EMT. Moreover, TGF- $\beta$ can induce EMT via non-canonical pathways, including the ERK1/2, GTPase, and p38 MAPK pathways [55]. It has been reported that $D C S T 1-A S 1$ increases TGF- $\beta$-induced EMT and DOX resistance via ANXA1 targeting in breast cancer cells. DCST1-AS1 inhibition also regulates TGF- $\beta$-induced production of MMP2 and MMP9 [61].

LncRNAs have a critical role in the chemoresistance of breast tumor cells through interactions with transcription factors. $C / E B P \beta$ is a transcription factor regulated by LINC00160, which targets TFF3. C/EBP $\beta$ is associated with a poor prognosis in estrogen receptor-negative and metastatic mammary tumors [62]. TFF3 is more highly expressed in metastatic breast cancer than in the non-metastatic type [63]. LINC00160 is associated with paclitaxel resistance and DOX resistance in MCF-7 and BT474 cells, respectively. Overexpression of LINCO0160 is correlated with poor overall survival in BC 
tissues. LINC00160 upregulated TFF3 via C/EBP $\beta$, which resulted in DOX-resistance in BT474 cells [64].

LncRNA in non-homologous end-joining pathway 1 (LINP1) is an oncogene that suppresses tumor growth and metastasis. LINP1 upregulation has a positive association with drug-resistance and unfavorable prognosis, and is seen in breast cancer cells resistant to 5-FU and doxorubicin. It has been reported that LINP1 regulates the cell cycle via CDK4, CCND1 and CCND3 modulations. LINP1 suppresses apoptosis and induces EMT process. There is a negative correlation between P53 and LINP1. The 5-FU and DOX resistance of breast cancer cells are increased by LINP1. LINP1 represses CASP9/ BAX and CASP8/9 expressions induced by 5-FU and DOX, respectively. There is also a correlation between the levels of LINP1 expression and tumor metastasis and stage [65].

H19 is an imprinted lncRNA that is only active when inherited maternally. H19 imprinting is regulated by a cis-acting upstream sequence that is involved in the regulation of DNA methylation and replication of parental chromosomes [66]. H19 has a pivotal role during tumorigenesis: its upregulation is observed in about $70 \%$ of breast cancer patients $[67,68]$. It has been reported that there is a significant $H 19$ upregulation in DOX-resistant $\mathrm{BC}$ cells. $H 19$ regulates DOX-resistance through upregulation of CUL4A and ABCB1/MDR1 [69]. Poly (ADP-ribose) polymerase (PARP) is involved in the detection of DNA damage. It employs DNA repair proteins through ADP-ribose binding. It is also involved in cell cycle and transcriptional regulations [70]. It has been reported that there is a significant $\mathrm{H} 19$ upregulation in $\mathrm{BC}$ tissues compared with their normal margins. There is also significant $H 19$ upregulation in DOX-resistant tissues and cell lines. H19 increases DOX-resistance via PARP-1 targeting in breast tumor cells [71].

\section{Osteosarcoma}

Osteosarcoma (OS) is the most frequent bone tumor among adolescents and children, accounting for up to $20 \%$ of bone malignancies. Cisplatin, doxorubicin, or methotrexate is considered to be the standard treatment methods for advanced osteosarcoma. However, $40-45 \%$ of osteosarcoma patients are resistant toward doxorubicin treatment [72]. Taurine upregulated gene 1 (TUG1) is an oncogenic lncRNA that is associated with chemoresistance in various cancers [73, 74]. TUG1 functions in post-transcriptional regulation through miRNA sponging and interacting with PRC2 complex [75]. TUG1 recruits EZH2 to downregulate CDK inhibitors such as p16 and p21 in gastric carcinoma (GC) [76]. It is also involved in tumor cell proliferation and migration through regulation of the Hedgehog, PI3K/AKT, and WNT signaling pathways in HCC and OS cells [77, 78]. Polydatin is a stilbenoid glucoside isolated from some plants that is involved in cell proliferation inhibition and apoptosis induction [79, 80]. AKT phosphorylation is critical for cell survival. TUG1 promotes osteosarcoma proliferation and invasion via AKT activation. In a positive feedback, AKT also upregulates TUG1 [81]. Polydatin inhibits tumor cells through suppression of the PI3K/AKT and PDGF/AKT pathways [81, 82]. It has been reported that polydatin inhibits osteosarcoma cell proliferation and reduces DOX-resistance via TUG1 downregulation. Since polydatin treatment in TUG1-silenced cells decreases AKT phosphorylation, inhibition of TUG1/AKT axis is required for its regulation of DOX-resistance in osteosarcoma cells [83]. 
Forkhead box $\mathrm{C} 2$ (FOXC2) is a critical transcription factor in tumor angiogenesis and MDR, functioning through EMT promotion [84]. ABCB1 plays a significant role in pumping external molecules through ATP hydrolysis that reduces the chemosensitivity of tumor cells [85]. FOXC2-AS1 is an lncRNA that regulates FOXC2 to promote DOX resistance via $\mathrm{ABCB} 1$ upregulation [86]. It is involved in the regulation of intracellular $\mathrm{Ca}^{2+}$ levels and the activation of the $\mathrm{Ca}^{2+}$-FAK signaling pathway [87]. It downregulates p15 and inhibits apoptosis via recruitment of EZH2 and SU212 [88]. FOXC2-AS1 and FOXC2 upregulations were observed in DOX-resistant osteosarcoma tissues and cell lines. FOXC2-AS1 is involved in FOXC2 upregulation through the formation of a stable RNA duplex, which upregulates ABCB1 in DOX-resistant osteosarcoma cells [86]. Simultaneous high expression levels of $F O X C 2-A S 1$ and $A B C B 1$ are the main reason for DOX-resistance in OS cells. Silencing FOXC2-AS1 and $A B C B 1$ reduces tumor growth during doxorubicin treatment. FOXC2-AS1 regulates the methylation of $\mathrm{ABCB} 1$ via PRC2, which results in ABCB1 downregulation [89].

As a ceRNAs, OIP5-AS1 upregulates WNT-7b and triggers the WNT pathway by targeting miR-410 [90]. It also regulates various signaling pathways, including $\mathrm{NOTCH}$ and PI3K/AKT [91, 92]. Significant OIP5-AS1 upregulations were shown in DOX-resistant OS tissues and cells compared to those in normal cells and chemosensitive tumor cells. Knockdown of OIP5-AS1 suppresses proliferation and promotes apoptosis. OIP5-AS1 has a pivotal role in the miR-137-3p sponging-mediated regulation of PTN expression [93]. Fibronectin-1 (FN1) is a pivotal glycoprotein associated with cell adhesion and motility [94]. It has a critical role in cisplatin, paclitaxel and gemcitabine responses through EMT regulation [95, 96]. Significant FN1 upregulations have been reported in DOX-resistant OS cell lines and tissues. OIP5-AS1 regulates FN1 expression through miR-200b-3p sponging [97].

SNHG12 is an lncRNA involved in the tumorigenesis of various cancers, including papillary thyroid carcinoma (PTC), GC, OS, and glioma [98-101]. It can affect the Wnt/ $\beta$-catenin pathway in PTC proliferation and metastasis [99]. It can also modulate the NOTCH2 pathway, which promotes OS metastasis and growth [101]. SNHG12 upregulates CRKL through miR-320 targeting that results in AKT/ERK activation in GC [102]. As a member of the BCL2 protein family, MCL1 plays a pivotal role in chemoresistance and apoptosis. It has been reported that SNHG12 decreases DOX sensitivity through miR-320a downregulation and MCL1 upregulation [103].

In vivo and in vitro experiments confirmed that doxorubicin-resistant OS cell lines and patients have higher expression levels of LINC00426 than their parental counterparts. Therefore, an unfavorable prognosis and no effective response to DOX are the consequences of LINC00426 overexpression. LINC00426 increases DOX resistance by targeting miR-4319 in OS cells [104].

CTA downregulation has been reported in DOX-resistant OS cells. CTA promotes apoptosis and suppresses autophagy by targeting miR-210 in OS cells. Its downregulation correlates with poor prognosis in OS patients. CTA significantly upregulates Casp8ap2 and AIFM3 [105].

ABCB1 is one of the MDR-associated genes involved in drug efflux from tumor cells [106]. FENDRR is an IncRNA involved in heart development through its binding to PRC2 and TrxG/MLL complexes [107]. A significant association has been reported 
between FENDRR downregulation and DOX-resistance in OS cells. FENDRR downregulates $\mathrm{ABCB} 1$ and $\mathrm{ABCC} 1$. It suppresses DOX resistance and induces OS cells apoptosis [108].

\section{Gastric cancer}

Gastric cancer (GC) remains one of the most frequent malignancies and the third leading cause of neoplasm-related death globally $[109,110]$. Approximately two-thirds of patients are detected in advanced tumor stages $[111,112]$. Although, there is an effective response to chemotherapy in GC patients with advanced tumors, drug resistance is also a major cause of tumor growth [113].

HOTAIR is a lncRNA that binds to PRC2 and the LSD1/CoREST/REST complex [114]. It also increases HOXA1 hypermethylation via DNMT1 and DNMT3b upregulations [115]. An association between HOTAIR upregulation and advanced stage GC tumors has been reported. HOTAIR increases DOX resistance, cell proliferation and migration by targeting miR-217, resulting in GPC5 and PTPN14 upregulations in GC cells [116].

Urothelial carcinoma associated 1 (UCA1) is a non-coding RNA that has been detected in bladder cancer for the first time [117]. It is in human endogenous retrovirus $\mathrm{H}$ gene family, which is highly expressed in malignant bladder cancer [117]. UCA1 upregulation promotes cell survival in bladder cancer during treatment with cisplatin [118]. It also induces DOX resistance in breast cancer tissue [119]. Its upregulation also positively correlates with poor differentiation, high grade, and poor overall survival. Knockdown of UCA1 inhibits tumor cell proliferation. DOX can promote apoptosis in SGC7901/DOX cells by silencing $U C A 1$, and also lead to cleavage of PARP protein and BCL-2 downregulation. UCA1 had an oncogenic role in GC via regulation of cell proliferation and DOX resistance [120].

$M i R-27 b$ is known as a tumor suppressor that is downregulated in GC $[121,122]$. It acts as an anti-angiogenic factor through its targeting of VEGF-C in GC [122]. Significant $U C A 1$ upregulation has been observed in GC tissues, which was negatively correlated with $m i R-27 b$. Downregulation of $U C A 1$ induces expression of $m i R-27 b$, resulting in a reduction in the level of anti-apoptotic proteins such as BCL2 and promotion of apoptotic proteins such as CASP3 in gastric tumor cells [123].

Myocyte enhancer factor 2D (MEF2D) is a transcription factor that is upregulated in various cancers, such as osteosarcoma [124], leukemia [125] and GC [126]. MEF2D has a key role in tumorigenesis, promoting proliferation, invasion and metastasis via repression of cell cycle arrest proteins, apoptosis, and the induction of the VEGF and TGF-b1 signaling pathways $[126,127]$. LncR-D63785 upregulation has been reported in gastric tumor cells. Reduced $\operatorname{lncR}$-D63785 expression represses cell proliferation, invasion and metastasis. LncR-D63785 downregulation promotes the DOX-sensitivity of GC cells to apoptosis via the miR-422a/MEF2D axis. The expression levels of KLK4, FOXG1, FOXQ1 and FOXE1 are also reduced by $m i R-422 a$. Positive correlations exist between the $\operatorname{lncR}$-D63785, miR422a and MEF2D expressions in DOX-resistant GC cells [128].

NEAT1 is a component of the paraspeckle nuclear bodies involved in the transcriptional regulation of various genes. It has an oncogenic role in various tumors, including GC $[129,130]$. NEAT1 upregulation that inhibited cell proliferation and invasion has 
been reported in GC. Its upregulation has also been observed in DOX-resistant GC cells [131].

MRUL is an lncRNA that upregulates P-gp in MDR gastric tumor cells. MRUL silencing significantly downregulate the Bcl-2/Bax ratio, RPS13, and RPL23 while significantly upregulating JNK1 and CPP32 in the presence of DOX. Drug-induced apoptosis increases following MRUL depletion in GC cells [132].

\section{Leukemia and lymphoma}

Acute myeloid leukemia (AML) is a heterogeneous bone marrow malignancy [133]. DOX is the most commonly prescribed chemotherapeutic agent for AML treatment, but chemoresistance is a big challenge [134].

KCNQ1OT1 is reported in vaious tumors $[135,136]$. It has interactions with G9a methyltransferase and the PRC2 complex [137]. Tetraspanin3 (Tspan3) is a cell-surface protein that regulates signal transductions in cell development, growth, the immune response and tumorigenesis [138]. Significant KCNQ1OT1 upregulation has been observed in DOX-resistant AML tissues. Its knockdown increases the DOX sensitivity and suppresses the cell proliferation and invasion of AML cells. It regulates the DOX response through $m i R-193 a-3 p$ targeting that inhibits Tspan3 [139].

Enhancer of zeste homolog 2 (EZH2) is a histone methyltransferase component of the PRC2 complex that can epigenetically methylate H3K27 to inhibit gene expression [140]. TUG1 overexpression has been reported in DOX-resistant AML tissues and cells. Interestingly, EZH2 is recruited through TUG1 to methylate and downregulate $m i R-34 a$, resulting in DOX resistance in AML cells [141].

HOXA-AS2 is located between the HOXA3 and HOXA4 genes. It acts as an oncogenic factor in promoting cell survival, proliferation and invasion [142, 143]. It is upregulated in various types of tumors and this state significantly correlates with poor prognosis. Its overexpression has been seen in patients who received DOX. HOXA-AS2 functions as a ceRNA of $m i R-520 c-3 p$ to upregulate S100A4, resulting in DOX-resistance of AML cells [144].

The PI3K/AKT/mTOR signaling pathway plays a pivotal role in the proliferation, differentiation and viability of hematopoietic cells $[145,146]$. A correlation between linc00239 expression and tumor cell proliferation and migration in AML cells has been observed. Linc00239 significantly increases the DOX-resistance of KG-1 and HL-60 cells through phosphorylation of $\mathrm{AKT}$ and mTOR, resulting in PI3K/ATK/mTOR pathway activation [147].

Chronic myeloid leukemia (CML) is a hematological malignancy resulting from BCRABL fusion [148]. Although CML cases respond effectively to tyrosine kinase inhibitors and chemotherapy [149], multidrug resistance proteins such as MDR1, P-gp and ABCB1 play a vital role in chemoresistance [150-152].

HuR is a member of RBP family. It stabilizes mRNA via binding to AU-rich elements, located in the 3'-UTRs of RNA [153, 154]. An association between FENDRR downregulation and MDR1 expression in DOX resistant CML cells has beenreported. FENDRR decreases the DOX-resistance of tumor cells by downregulating MDR1 through HuR and targeting miR-184 in CML cells [155]. 
DOX is one of the common treatments for Burkitt lymphoma (BL) [156], although the majority of patients have no DOX response [157]. PI3K/AKT/mTOR is a nominated pathway in lymphoma chemoresistance. Eukaryotic translation initiation factor $4 \mathrm{E}$ (EIF4E) is a target of the mTOR pathway, which can affect numerous cancer phenotypes $[158,159]$. MCM3AP-AS1 reportedly increases the DOX resistance of BL cells through miR-15a sponging and EIF4E upregulation [160].

\section{Liver cancer}

Hepatocellular carcinoma (HCC) is one of the leading causes of cancer-related death in the world [161, 162]. MALAT1 is an oncogenic lncRNA that promotes tumor progression and chemoresistance through various mechanisms, such as miRNA sponging and autophagy induction [163]. It is involved in alternative splicing via regulation of SR proteins [164]. It has also critical roles in various signaling pathways, such as Hippo, PI3KAKT, MAPK, WNT and NF- $\mathrm{kB}$ [165-168]. MALAT1 upregulation has been shown in MDR-HCC cells. HIF-2a upregulates MALAT1, which subsequently targets miR-216b during MDR regulation in HCC cells [169].

Neuro-oncological ventral antigen 1 (Nova1) is a neuron-specific RNA-binding protein that functions as an oncogene involved in the aberrant immune response [170], the resistance of cancer cells to hypoxia-related apoptosis induction [171], and tumor progression [172]. Nova1 upregulation has been observed in Huh-7 cells, and is associated with cell proliferation, migration, invasion and poor prognosis in HCC [173].

MALAT1 and Nova1 upregulations have been reported for DOX-resistant hepatic tumor cells in comparison with DOX-sensitive cells. MALAT1 upregulation correlates with tumor cell proliferation, invasion and chemoresistance through Noval regulation. It sponges miR-3129-5p in DOX-resistant cells. MALAT1 depletion triggered DOXresistance in HCC cells by repressing the proliferation, migration, invasion and promotion of apoptosis through the MALAT1/miR-3129-5p/Nova1 axis [174].

NEAT1 has an important role in the integrity of paraspeckles. Its upregulation has been observed in sorafenib- and DOX-resistant HCC cells. Paraspeckles have been observed in DOX-resistant HCC cells [175].

LncARSR is activated by AKT to target miR-34 and miR-449, which results in sunitinib resistance of renal cancer cells through AXL and c-MET upregulations [176]. Correlations have been shown between IncARSR upregulation and the large tumor size, advanced BCLC stage, poor prognosis, and DOX resistance of HCC cells. LncARSR induces DOX resistance in both in vitro and in vivo studies through PTEN targeting that activates the PI3K-AKT signaling pathway [177].

Growth arrest-specific 5 (GAS5) is an lncRNA associated with a variety of biological mechanisms, such as cell proliferation, survival and DOX resistance, via regulation of The miR-21/PTEN axis. GAS5 upregulation in HCC cells is associated with metastasis to lymph nodes and shorter overall survival time in HCC patients. It also has a key role in DOX-resistance in both in vitro and in vivo studies. GAS5 inhibits the expression of miR-21, which results in PTEN upregulation [178]. H19 is a maternally expressed gene product that functions as a tumor suppressor or oncogene. H19 reportedly inhibits HCC cell proliferation following sorafenib or doxorubicin treatments [179]. 


\section{Colorectal cancer}

LncRNA X-inactive specific transcript (XIST) is considered the most significant regulator of $\mathrm{X}$ chromosome inactivation in mammals via the PRC complex [180]. It also promotes NOTCH signaling by targeting miR-137, which results in NOTCH-1 upregulation [181]. It has been suggested that the deregulation of XIST plays an important role in tumor progression and prognosis [182].

Overexpression of serum and glucocorticoid-regulated kinase 1 (SGK1; one of the AGC serine/threonine protein kinases) has been associated with proliferative activity, apoptosis, adhesion and drug-resistance in numerous types of epithelial cancer [183, 184]. There is a correlation between SGK1 and DOX-mediated apoptosis in renal cancer [185]. Downregulation of SGK1 reduces cell proliferation and migration and promotes 5-FU-mediated apoptosis induction [186]. XIST upregulation has been reported in DOX-resistant CRC cells. XIST increases DOX resistance through miR-124 sponging that results in SGK1 upregulation in CRC cells [187].

BRAF-activated noncoding RNA (BANCR) is an lncRNA involved in tumorigenesis in various cancer types, such as lung cancer, GC, thyroid cancer and osteosarcoma [188]. Chromosomal segregation 1-like (CSE1L) plays a critical role in apoptosis, survival, chromosome assembly, nuclear transportation, microvesicle formation and metastasis [189, 190]. BANCR and CSE1L overexpressions have been observed in CRC cells. Direct correlations have been found between CSE1L and BANCR expressions and the clinicopathological features of CRC. BANCR increases CSE1L expression through miR-203 sponging in CRC tissue. There is significant miR-203 downregulation in CRC cells in comparison with controls. BANCR downregulation inhibits tumor progression and promotes the sensitivity of CRC cells to DOX by modulating the miR-203/CSE1L axis [191].

The NODAL signaling pathway has a key role in the regulation of chemoresistance in cancer stem cells (CSCs) [192, 193]. NODAL signaling can be protected by GAS5, contributing to the preservation and chemoresistance of CSCs. GAS5 is a pivotal factor in the proliferation of CSCs, and thus to tumor promotion and metastasis. It also plays a key role in drug-resistance. Knockdown of GAS5 improves chemo-sensitivity and apoptosis in the tumor cells treated with 5-FU and DOX [194].

\section{Thyroid and gall bladder cancers}

Thyroid cancer remains the most frequent endocrine malignancy worldwide. It has a high mortality rate [195]. Anaplastic thyroid carcinoma (ATC) is the most aggressive and recurrent type of thyroid tumor that is commonly treated with DOX [196]. However, overexpression of multidrug resistance proteins causes drug resistance in such patients [197].

Signal transducer and activator of transcription 3 (STAT3) is a transcription factor activated by cytokines and growth factors involved in inflammation, tumor cell proliferation and invasion [198-200]. INO80 is involved in DNA repair and transcription [201]. Lipoprotein receptor-related protein 6 (LRP6) is targeted by PTCSC3, resulting in repression of glioma cell proliferation via suppression of WNT signaling pathway [202]. It has been reported that PTCSC3 downregulates INO80 by targeting STAT3, which reduces the DOX-resistance of ATC [203]. 
Gallbladder cancer is the most aggressive cancer type observed in the biliary tract. It ranks as the fifth most frequent malignancy in digestive tracts worldwide. Many patients have poor prognosis because of diagnosis in the advanced stage due to the unclear and non-specific symptoms. Autophagy has a paradoxical role in oncogenesis. The cytoprotective role of autophagy leads to stress tolerance which enables tumor resistance toward chemotherapy [204].

Gallbladder cancer drug resistance-associated lncRNA1 (GBCDRlnc1) is a unique lncRNA mediating resistance to chemotherapy. GBCDRlnc1 upregulation has been reported in gallbladder tumor cells. GBCDRlnc1 maintained PGK1 stability by inhibiting its ubiquitination leading to ATG5 and ATG12 downregulations in DOX-resistant tumor cells. GBCDRlnc1 upregulation correlates with poorer histological grade and advanced tumor stage [205].

\section{Prostate and urothelial cancers}

PRC2 is in the methyltransferase protein family, which methylates lysine of histone H3 to suppress gene expression. The PRC2 complex is comprised of several components, including EZH1, EZH2, SUZ12 and EED [206, 207]. Significant LINC-PINT upregulation has been observed in clear cell renal cell carcinoma (ccRCC) cells, correlating with sex, $\mathrm{pT}$ and tumor stage. The LINC-PINT levels also negatively correlate with DFS and OS in patients. LINC-PINT induces cell proliferation, but represses apoptosis via EZH2 targeting in ccRCC cells. DOX upregulates P53 and LINC-PINT in ccRCC tissues [208].

GAS5 is a tumor suppressor that is downregulated in HCC, GC and ovarian cancer [209-211]. Its downregulation has also been reported in bladder transitional cell carcinoma (BTCC) tissues and cells, where it is associated with higher grades of cancer. It inhibits cell proliferation and DOX resistance in BTCC cells through downregulation of BCL-2 [212]. There are also HOTAIR upregulations in transitional cell carcinoma (TCC) tissues and cells and these correlate with higher histological grades, shorter overall survival, and reduced DOX sensitivity [213].

Lysyl oxidase-like 1 (LOXL1) is an extracellular matrix (ECM) protein in the the copper-dependent monoamine lysyl oxidase family, which is involved in oxidation of collagens and elastin [214]. LOXL1-AS1 is located in the opposite strand of LOXL1 [215]. The epidermal growth factor receptor (EGFR) is a member of the receptor tyrosine kinases (RTK) family, participating in cell proliferation, differentiation and tumor progression [216, 217]. Overexpression of EGFR has been reported in a variety of tumor types [218]. It has been reported that EGFR regulates LOXL1-AS1 expression via miR-let-7a-5p in prostate cancer $(\mathrm{PCa})$ cells. LOXL1-AS1 is downregulated in DOX-resistant PCa cells compared with DOX-sensitive cells. There is a significant miR-let-7a-5p upregulation in DOX-resistant PCa cells. MiR-let-7a-5p reduces the promoting role of LOXL1-AS1 on DOX-resistant cell proliferation [219].

\section{Conclusions}

Despite its wide clinical applications, DOX can affect the quality of life of cancer patients due to side effects during and after treatment. Clarifying the molecular basis of DOX resistance is essential for the development of novel therapeutic strategies with fewer and less impactful side effects in cancer patients. LncRNAs have critical 
roles in drug resistance in various tumors. In this review, we have summarized the current state of knowledge on all the lncRNAs associated with DOX resistance in various tumors. This should pave the way to introducing an lncRNA panel marker for the prediction of the DOX response among cancer patients. The majority of lncRNAs promote DOX-resistance in the various tumor types.

\section{Abbreviations}

DOX: Doxorubicin; IncRNAs: Long non-coding RNAs; EMT: Epithelial-mesenchymal transition; ADR: Adriamycin; MDR: Multidrug resistance; MRP1: Multidrug resistance protein 1; ABC: ATP-binding cassette; ANXA1: Annexin A1; PARP: Poly ADP-ribose polymerase; OS: Osteosarcoma; TUG1:Taurine upregulated gene 1; FN1: Fibronectin-1; PTC: Papillary thyroid carcinoma; GC: Gastric carcinoma; UCA1: Urothelial carcinoma associated 1; AML: Acute myeloid leukemia; Tspan3: Tetraspanin 3; CML: Chronic myeloid leukaemia; BL: Burkitt lymphoma; EIF4E: Eukaryotic translation initiation factor 4E; HCC: Hepatocellular carcinoma; Nova1: Neuro-oncological ventral antigen 1; XIST: X-inactive specific transcript; BANCR: BRAF-activated noncoding RNA; CSE1L: Chromosomal segregation 1-like; GAS5: Growth arrest-specific 5; ATC: Anaplastic thyroid carcinoma; LRP6: Lipoprotein receptor related protein 6; GBCDRInc1: Gallbladder cancer drug resistanceassociated IncRNA1; ECM: Extracellular matrix; EGFR: Epidermal growth factor receptor; RTK: Receptor tyrosine kinases; PCa: Prostate cancer; ANLN: Anillin actin binding protein; LINP1: LncRNA in non-homologous end-joining pathway 1; FOXC2: Forkhead box C2; MEF2D: Myocyte enhancer gactor 2D; EZH2: Enhancer of zeste homolog 2; SGK1: Serum and glucocorticoid-regulated kinase 1; STAT3: Signal transducer and activator of transcription 3; LOXL1: Lysyl oxidase-like 1; BTCC: Bladder transitional cell carcinoma; TCC: Transitional cell carcinoma.

\section{Acknowledgements}

Not applicable.

\section{Authors' contributions}

GKT was involved in creating the search strategy and drafting the manuscript. MM supervised the project and revised and edited the manuscript. All authors read and approved the final manuscript.

\section{Funding}

Not applicable.

Availability of data and materials

The datasets used and/or analyzed during this study are available from the corresponding author on reasonable request.

\section{Declarations}

Ethics approval and consent to participate

Not applicable

\section{Consent for publication}

Not applicable.

\section{Competing interests}

The authors declare that they have no competing interests.

Received: 21 April 2021 Accepted: 17 August 2021

Published online: 23 August 2021

\section{References}

1. Szakács G, Paterson JK, Ludwig JA, Booth-Genthe C, Gottesman MM. Targeting multidrug resistance in cancer. Nat Rev Drug Discovery. 2006;5(3):219-34

2. Moghbeli M. Genetic and molecular biology of breast cancer among Iranian patients. J Transl Med. 2019;17(1):218

3. Maeda $\mathrm{H}$, Khatami M. Analyses of repeated failures in cancer therapy for solid tumors: poor tumor-selective drug delivery, low therapeutic efficacy and unsustainable costs. Clin Transl Med. 2018;7(1):1-20.

4. Zheng HC. The molecular mechanisms of chemoresistance in cancers. Oncotarget. 2017;8(35):59950-64.

5. Zhang X, Peng X, Yu W, Hou S, Zhao Y, Zhang Z, et al. Alpha-tocopheryl succinate enhances doxorubicin-induced apoptosis in human gastric cancer cells via promotion of doxorubicin influx and suppression of doxorubicin efflux. Cancer Lett. 2011;307(2):174-81.

6. Bamodu OA, Huang W-C, Tzeng DT, Wu A, Wang LS, Yeh C-T, et al. Ovatodiolide sensitizes aggressive breast cancer cells to doxorubicin, eliminates their cancer stem cell-like phenotype, and reduces doxorubicin-associated toxicity. Cancer Lett. 2015:364(2):125-34.

7. Carvalho C, Santos RX, Cardoso S, Correia S, Oliveira PJ, Santos MS, et al. Doxorubicin: the good, the bad and the ugly effect. Curr Med Chem. 2009;16(25):3267-85. 
8. Kubiliute R, Januskeviciene I, Urbanaviciute R, Daniunaite K, Drobniene M, Ostapenko V, et al. Nongenotoxic $\mathrm{ABCB} 1$ activator tetraphenylphosphonium can contribute to doxorubicin resistance in MX-1 breast cancer cell line. Sci Rep. 2021;11(1):1-11.

9. Allen JD, Jackson SC, Schinkel AH. A mutation hot spot in the Bcrp1 (Abcg2) multidrug transporter in mouse cell lines selected for Doxorubicin resistance. Can Res. 2002;62(8):2294-9.

10. Conrad S, Kauffmann H-M, Ito K-I, Leslie EM, Deeley RG, Schrenk D, et al. A naturally occurring mutation in MRP1 results in a selective decrease in organic anion transport and in increased doxorubicin resistance. Pharmacogenetics Genomics. 2002;12(4):321-30.

11. Aas T, Børresen A-L, Geisler S, Smith-Sørensen B, Johnsen H, Varhaug JE, et al. Specific P53 mutations are associated with de novo resistance to doxorubicin in breast cancer patients. Nat Med. 1996;2(7):8114.

12. Fimognari C, Lenzi M, Sciuscio D, Cantelli-Forti G, Hrelia P. Combination of doxorubicin and sulforaphane for reversing doxorubicin-resistant phenotype in mouse fibroblasts with p53Ser220 mutation. Ann New York Acad Sci. 2007;1095(1):62-9.

13. Cao X, Hou J, An Q, Assaraf YG, Wang X. Towards the overcoming of anticancer drug resistance mediated by p53 mutations. Drug Resist Updates. 2020;49:100671.

14. Calcabrini C, Maffei F, Turrini E, Fimognari C. Sulforaphane potentiates anticancer effects of doxorubicin and cisplatin and mitigates their toxic effects. Front Pharmacol. 2020;1 1:567.

15. Sumarpo A, Ito K, Saiki Y, Ishizawa K, Wang R, Chen N, et al. Genetic and epigenetic aberrations of ABCB1 synergistically boost the acquisition of taxane resistance in esophageal squamous cancer cells. Biochem Biophys Res Commun. 2020;526(3):586-91.

16. Ponnusamy L, Mahalingaiah PKS, Chang Y-W, Singh KP. Reversal of epigenetic aberrations associated with the acquisition of doxorubicin resistance restores drug sensitivity in breast cancer cells. Eur J Pharm Sci. 2018;123:56-69.

17. Ai L, Kim W-J, Demircan B, Dyer LM, Bray KJ, Skehan RR, et al. The transglutaminase 2 gene (TGM2), a potential molecular marker for chemotherapeutic drug sensitivity, is epigenetically silenced in breast cancer. Carcinogenesis. 2008;29(3):510-8.

18. Maruyama R, Suzuki H. Long noncoding RNA involvement in cancer. BMB Rep. 2012;45(11):604.

19. Bartoszewski R, Sikorski AF. Editorial focus: entering into the non-coding RNA era. Cell Mol Biol Lett. 2018;23:45.

20. Magistri M, Faghihi MA, Wahlestedt C. Regulation of chromatin structure by long noncoding RNAs: focus on natural antisense transcripts. Trends Genet. 2012;28(8):389-96.

21. Rahmani Z, Mojarrad M, Moghbeli M. Long non-coding RNAs as the critical factors during tumor progressions among Iranian population: an overview. Cell Biosci. 2020;10:6.

22. Zangouei AS, Rahimi HR, Mojarrad M, Moghbeli M. Non coding RNAs as the critical factors in chemo resistance of bladder tumor cells. Diagn Pathol. 2020;15(1):136.

23. Moghbeli M. Molecular interactions of miR-338 during tumor progression and metastasis. Cell Mol Biol Lett. 2021;26(1):13.

24. Liu Y, Huang R, Xie D, Lin X, Zheng L. ZNF674-AS1 antagonizes miR-423-3p to induce G0/G1 cell cycle arrest in non-small cell lung cancer cells. Cell Mol Biol Lett. 2021;26(1):6.

25. Lv M, Mao Q, Li J, Qiao J, Chen X, Luo S. Knockdown of LINC00665 inhibits proliferation and invasion of breast cancer via competitive binding of miR-3619-5p and inhibition of catenin beta 1. Cell Mol Biol Lett. 2020;25:43.

26. Yang S, Liu T, Sun Y, Liang X. The long noncoding RNA LINC00483 promotes lung adenocarcinoma progression by sponging miR-204-3p. Cell Mol Biol Lett. 2019;24:70.

27. Wang H, Guan Z, He K, Qian J, Cao J, Teng L. LncRNA UCA1 in anti-cancer drug resistance. Oncotarget. 2017:8(38):64638.

28. Chen QN, Wei CC, Wang ZX, Sun M. Long non-coding RNAs in anti-cancer drug resistance. Oncotarget. 2017:8(1):1925-36.

29. Zhou Y, Sun W, Qin Z, Guo S, Kang Y, Zeng S, et al. LncRNA regulation: New frontiers in epigenetic solutions to drug chemoresistance. Biochem Pharmacol. 2020:114228.

30. Leone J, Leone BA, Leone JP. Adjuvant systemic therapy in older women with breast cancer. Breast Cancer: Targets Therapy. 2016:8:141.

31. Tzanninis I-G, Kotteas EA, Ntanasis-Stathopoulos I, Kontogianni P, Fotopoulos G. Management and outcomes in metaplastic breast cancer. Clin Breast Cancer. 2016;16(6):437-43.

32. Palmieri C, Krell J, James CR, Harper-Wynne C, Misra V, Cleator S, et al. Rechallenging with anthracyclines and taxanes in metastatic breast cancer. Nat Rev Clin Oncol. 2010;7(10):561.

33. Gonzalez-Angulo AM, Morales-Vasquez F, Hortobagyi GN. Overview of resistance to systemic therapy in patients with breast cancer. Breast Cancer Chemosensitivity: Springer; 2007. p. 1-22.

34. Zhang M, Wang F, Xiang Z, Huang T, Zhou WB. LncRNA XIST promotes chemoresistance of breast cancer cells to doxorubicin by sponging miR-200c-3p to upregulate ANLN. Clin Exp Pharmacol Physiol. 2020;47(8):1464-72.

35. Deng X, Fang Zhao X, Qiu Liang X, Chen R, Feng Pan Y, Liang J. Linc00152 promotes cancer progression in hepatitis B virus-associated hepatocellular carcinoma. Biomed Pharmacother. 2017;90:100-8.

36. Zhang P-p, Wang Y-q, Weng W-w, Nie W, Wu Y, Deng Y, et al. Linc00152 promotes cancer cell proliferation and invasion and predicts poor prognosis in lung adenocarcinoma. J Cancer. 2017;8(11):2042.

37. Zhang Y-H, Fu J, Zhang Z-J, Ge C-C, Yi Y. LncRNA-LINC00152 down-regulated by miR-376c-3p restricts viability and promotes apoptosis of colorectal cancer cells. Am J Transl Res. 2016;8(12):5286.

38. Nötzold L, Frank L, Gandhi M, Polycarpou-Schwarz M, Groß M, Gunkel M, et al. The long non-coding RNA LINC00152 is essential for cell cycle progression through mitosis in HeLa cells. Sci Rep. 2017;7(1):1-13.

39. Moghbeli M, Forghanifard MM, Sadrizadeh A, Mozaffari HM, Golmakani E, Abbaszadegan MR. Role of Msi1 and MAML1 in regulation of notch signaling pathway in patients with esophageal squamous cell carcinoma. J Gastrointest Cancer. 2015;46(4):365-9.

40. Moghbeli M, Rad A, Farshchian M, Taghehchian N, Gholamin M, Abbaszadegan MR. Correlation between Meis1 and Msi1 in esophageal squamous cell carcinoma. J Gastrointest Cancer. 2016;47(3):273-7. 
41. Hu X, Wang J, He W, Zhao P, Wu W. Down-regulation of IncRNA Linc00152 suppressed cell viability, invasion, migration, and epithelial to mesenchymal transition, and reversed chemo-resistance in breast cancer cells. Eur Rev Med Pharmacol Sci. 2018;22(10):3074-84.

42. Munoz $M$, Henderson $M$, Haber M, Norris M. Role of the MRP1/ABCC1 multidrug transporter protein in cancer. IUBMB Life. 2007;59(12):752-7.

43. Lu JF, Pokharel D, Bebawy M. MRP1 and its role in anticancer drug resistance. Drug Metab Rev. 2015;47(4):406-19.

44. Chang L, Hu Z, Zhou Z, Zhang H. Linc00518 contributes to multidrug resistance through regulating the MiR-199a/ MRP1 axis in breast cancer. Cell Physiol Biochem. 2018;48(1):16-28.

45. Page C, Lin HJ, Jin Y, Castle VP, Nunez G, Huang M, et al. Overexpression of Akt/AKT can modulate chemotherapyinduced apoptosis. Anticancer Res. 2000;20(1A):407-16.

46. Austreid E, Lonning PE, Eikesdal HP. The emergence of targeted drugs in breast cancer to prevent resistance to endocrine treatment and chemotherapy. Expert Opin Pharmacother. 2014;15(5):681-700.

47. Wang Z, Huang Y, Zhang J. Molecularly targeting the PI3K-Akt-mTOR pathway can sensitize cancer cells to radiotherapy and chemotherapy. Cell Mol Biol Lett. 2014;19(2):233-42.

48. Li Z, Qian J, Li J, Zhu C. Knockdown of IncRNA-HOTAIR downregulates the drug-resistance of breast cancer cells to doxorubicin via the PI3K/AKT/mTOR signaling pathway. Exp Ther Med. 2019;18(1):435-42.

49. Geng S-Q, Alexandrou AT, Li JJ. Breast cancer stem cells: multiple capacities in tumor metastasis. Cancer Lett. 2014;349(1):1-7.

50. Yu L, Di Y, Xin L, Ren Y, Liu X, Sun X, et al. SND1 acts as a novel gene transcription activator recognizing the conserved Motif domains of Smad promoters, inducing TGF $\beta 1$ response and breast cancer metastasis. Oncogene. 2017;36(27):3903-14.

51. Arretxe E, Armengol S, Mula S, Chico Y, Ochoa B, Martínez MJ. Profiling of promoter occupancy by the SND1 transcriptional coactivator identifies downstream glycerolipid metabolic genes involved in TNFa response in human hepatoma cells. Nucleic Acids Res. 2015;43(22):10673-88.

52. Yang J, Välineva T, Hong J, Bu T, Yao Z, Jensen ON, et al. Transcriptional co-activator protein p100 interacts with snRNP proteins and facilitates the assembly of the spliceosome. Nucleic Acids Res. 2007:35(13):4485-94.

53. Leverson JD, Koskinen PJ, Orrico FC, Rainio E-M, Jalkanen KJ, Dash AB, et al. Pim-1 kinase and p100 cooperate to enhance c-Myb activity. Mol Cell. 1998;2(4):417-25.

54. Qian W, Zhu Y, Wu M, Guo Q, Wu Z, Lobie PE, et al. Linc00668 promotes invasion and stem cell-like properties of breast cancer cells by interaction with SND1. Front Oncol. 2020;10:88.

55. Zarzynska JM. Two faces of TGF-beta1 in breast cancer. Mediators Inflammation. 2014;2014.

56. Horne HN, Oh H, Sherman ME, Palakal M, Hewitt SM, Schmidt MK, et al. E-cadherin breast tumor expression, risk factors and survival: pooled analysis of 5,933 cases from 12 studies in the Breast Cancer Association Consortium. Sci Rep. 2018;8(1):1-11.

57. Li C-F, Chen J-Y, Ho Y-H, Hsu W-H, Wu L-C, Lan H-Y, et al. Snail-induced claudin-11 prompts collective migration for tumour progression. Nat Cell Biol. 2019;21(2):251-62.

58. Richardson AM, Havel LS, Koyen AE, Konen JM, Shupe J, Wiles Wt, et al. Vimentin is required for lung adenocarcinoma metastasis via heterotypic tumor cell-cancer-associated fibroblast interactions during collective invasion. Clin Cancer Res. 2018;24(2):420-32.

59. Senchenkova EY, Ansari J, Becker F, Vital SA, Al-Yafeai Z, Sparkenbaugh EM, et al. Novel role for the AnXA1-Fpr2/ ALX signaling axis as a key regulator of platelet function to promote resolution of inflammation. Circulation. 2019;140(4):319-35.

60. Sheikh MH, Solito E. Annexin A1: uncovering the many talents of an old protein. Int J Mol Sci. 2018;19(4):1045.

61. Tang L, Chen Y, Chen H, Jiang P, Yan L, Mo D, et al. DCST1-AS1 promotes TGF- $\beta$-induced epithelial-mesenchymal transition and enhances chemoresistance in triple-negative breast cancer cells via ANXA1. Front Oncol. 2020;10:280.

62. Milde-Langosch K, Löning T, Bamberger A-M. Expression of the CCAAT/enhancer-binding proteins C/EBPa, C/EBP $\beta$ and C/EBPS in breast cancer: correlations with clinicopathologic parameters and cell-cycle regulatory proteins. Breast Cancer Res Treat. 2003;79(2):175-85.

63. Elnagdy MH, Farouk O, Seleem AK, Nada HA. TFF1 and TFF3 mRNAs are higher in blood from breast cancer patients with metastatic disease than those without. J Oncol. 2018;2018.

64. Wu H, Gu J, Zhou D, Cheng W, Wang Y, Wang Q, et al. LINC00160 mediated paclitaxel-And doxorubicin-resistance in breast cancer cells by regulating TFF3 via transcription factor C/EBP $\beta$. J Cell Mol Med. 2020;24(15):8589-602.

65. Liang $Y$, Li Y, Song $X$, Zhang N, Sang Y, Zhang H, et al. Long noncoding RNA LINP1 acts as an oncogene and promotes chemoresistance in breast cancer. Cancer Biol Ther. 2018;19(2):120-31.

66. Drewell RA, Brenton JD, Ainscough JF, Barton SC, Hilton KJ, Arney KL, et al. Deletion of a silencer element disrupts H19 imprinting independently of a DNA methylation epigenetic switch. Development. 2000;127(16):3419-28.

67. Raveh E, Matouk IJ, Gilon M, Hochberg A. The H19 Long non-coding RNA in cancer initiation, progression and metastasis-a proposed unifying theory. Mol Cancer. 2015;14(1):184.

68. ZhangEB H. c-Myc-induced, long, noncoding H19 affects cell proliferation and predicts a poor prognosis in patients with gastric cancer. Med Oncol. 2014;31(5):914.

69. Zhu Q-N, Wang G, Guo Y, Peng Y, Zhang R, Deng J-L, et al. LncRNA H19 is a major mediator of doxorubicin chemoresistance in breast cancer cells through a cullin4A-MDR1 pathway. Oncotarget. 2017;8(54):91990.

70. Gibson BA, Kraus WL. New insights into the molecular and cellular functions of poly (ADP-ribose) and PARPs. Nat Rev Mol Cell Biol. 2012;13(7):41124.

71. Wang Y, Zhou P, Li P, Yang F, Gao X-q. Long non-coding RNA H19 regulates proliferation and doxorubicin resistance in MCF-7 cells by targeting PARP1. Bioengineered. 2020;11(1):536-46.

72. Buondonno I, Gazzano E, Jean SR, Audrito V, Kopecka J, Fanelli M, et al. Mitochondria-targeted doxorubicin: a new therapeutic strategy against doxorubicin-resistant osteosarcoma. Mol Cancer Ther. 2016;15(11):2640-52.

73. Li Z, Shen J, Chan MT, Wu WKK. TUG 1: a pivotal oncogenic long non-coding RNA of human cancers. Cell Prolif. 2016;49(4):471-5. 
74. Wang $\mathrm{Q}$, Chen $\mathrm{Q}$. Role of taurine upregulated gene 1 as a predictor of poor outcome in osteosarcoma. J Cancer Res Ther. 2018;14(9):405.

75. Lin P-C, Huang H-D, Chang C-C, Chang Y-S, Yen J-C, Lee C-C, et al. Long noncoding RNA TUG1 is downregulated in non-small cell lung cancer and can regulate CELF1 on binding to PRC2. BMC Cancer. 2016;16(1):1-10.

76. Zhang E, He X, Yin D, Han L, Qiu M, Xu T, et al. Increased expression of long noncoding RNA TUG1 predicts a poor prognosis of gastric cancer and regulates cell proliferation by epigenetically silencing of $\mathrm{p} 57$. Cell Death Dis. 2016;7(2):e2109.

77. Li J, Zhang Q, Fan X, Mo W, Dai W, Feng J, et al. The long noncoding RNA TUG1 acts as a competing endogenous RNA to regulate the Hedgehog pathway by targeting miR-132 in hepatocellular carcinoma. Oncotarget. 2017:8(39):65932.

78. Wang $Y$, Yang T, Zhang Z, Lu M, Zhao W, Zeng $X$, et al. Long non-coding RNA TUG 1 promotes migration and invasion by acting as a ce RNA of miR-335-5p in osteosarcoma cells. Cancer Sci. 2017;108(5):859-67.

79. Zou J, Yang Y, Yang Y, Liu X. Polydatin suppresses proliferation and metastasis of non-small cell lung cancer cells by inhibiting NLRP3 inflammasome activation via NF-KB pathway. Biomed Pharmacother. 2018;108:130-6.

80. Cao WJ, Wu K, Wang C, Wan DM. Polydatin-induced cell apoptosis and cell cycle arrest are potentiated by Janus kinase 2 inhibition in leukemia cells. Mol Med Rep. 2016;13(4):3297-302.

81. Jin Y-L, Xin L-M, Zhou C-C, Ren Y. Polydatin exerts anti-tumor effects against renal cell carcinoma cells via induction of caspase-dependent apoptosis and inhibition of the PI3K/Akt pathway. Onco Targets Ther. 2018;11:8185.

82. Li H, Shi B, Li Y, Yin F. Polydatin inhibits cell proliferation and induces apoptosis in laryngeal cancer and HeLa cells via suppression of the PDGF/AKT signaling pathway. J Biochem Mol Toxicol. 2017;31(7):e21900.

83. Hu T, Fei Z, Su H, Xie R, Chen L. Polydatin inhibits proliferation and promotes apoptosis of doxorubicin-resistant osteosarcoma through LncRNA TUG1 mediated suppression of Akt signaling. Toxicol Appl Pharmacol. 2019;371:55-62

84. Kume T. The role of FoxC2 transcription factor in tumor angiogenesis. J Oncol. 2012;2012.

85. Lee $\mathrm{CH}$. Reversing agents for ATP-binding cassette (ABC) transporters: application in modulating multidrug resistance (MDR). Curr Med Chem-Anti-Cancer Agents. 2004;4(1):43-52.

86. Zhang C-L, Zhu K-P, Ma X-L. Antisense IncRNA FOXC2-AS1 promotes doxorubicin resistance in osteosarcoma by increasing the expression of FOXC2. Cancer Lett. 2017;396:66-75.

87. Pan K, Xie Y. LncRNA FOXC2-AS1 enhances FOXC2 mRNA stability to promote colorectal cancer progression via activation of Ca 2+-FAK signal pathway. Cell Death Dis. 2020;11(6):1-14.

88. Xu D, Tao X, Yu Y, Teng Y, Huang Y, Ma J, et al. LncRNA FOXC2-AS1 stimulates proliferation of melanoma via silencing p15 by recruiting EZH2. Eur Rev Med Pharmacol Sci. 2020;24(17):8940-6.

89. Zhang C-L, Zhu K-P, Shen G-Q, Zhu Z-S. A long non-coding RNA contributes to doxorubicin resistance of osteosarcoma. Tumor Biol. 2016;37(2):2737-48.

90. Sun WL, Kang T, Wang YY, Sun JP, Li C, Liu HJ, Yang Y, Jiao BH. Long noncoding RNA OIP5-AS1 targets Wnt-7b to affect glioma progression via modulation of miR-410. Biosci Rep. 2019;39(1):BSR20180395.

91. Hu G-w, Wu L, Kuang W, Chen Y, Zhu X-g, Guo H, et al. Knockdown of linc-OIP5 inhibits proliferation and migration of glioma cells through down-regulation of YAP-NOTCH signaling pathway. Gene. 2017;610:24-31.

92. Yang $\mathrm{N}$, Chen J, Zhang H, Wang $X$, Yao H, Peng Y, et al. LncRNA OIP5-AS1 loss-induced microRNA-410 accumulation regulates cell proliferation and apoptosis by targeting KLF10 via activating PTEN/PI3K/AKT pathway in multiple myeloma. Cell Death Dis. 2017;8(8):e2975.

93. Sun X, Tian C, Zhang H, Han K, Zhou M, Gan Z, et al. Long noncoding RNA OIP5-AS1 mediates resistance to doxorubicin by regulating miR-137-3p/PTN axis in osteosarcoma. Biomed Pharmacother. 2020;128:110201.

94. Topalovski M, Brekken RA. Matrix control of pancreatic cancer: new insights into fibronectin signaling. Cancer Lett. 2016;381(1):252-8.

95. Gao W, Liu Y, Qin R, Liu D, Feng Q. Silence of fibronectin 1 increases cisplatin sensitivity of non-small cell lung cancer cell line. Biochem Biophys Res Commun. 2016;476(1):35-41.

96. Wu W, Wang Q, Yin F, Yang Z, Zhang W, Gabra H, et al. Identification of proteomic and metabolic signatures associated with chemoresistance of human epithelial ovarian cancer. Int J Oncol. 2016;49(4):1651-65.

97. Kun-Peng Z, Chun-Lin Z, Xiao-Long M, Lei Z. Fibronectin-1 modulated by the long noncoding RNA OIP5-AS1/miR200b-3p axis contributes to doxorubicin resistance of osteosarcoma cells. J Cell Physiol. 2019;234(5):6927-39.

98. Yang B, Cai W, Chen B. LncRNA SNHG12 regulated the proliferation of gastric carcinoma cell BGC-823 by targeting microRNA-199a/b-5p. Eur Rev Med Pharmacol Sci. 2018;22(5):1297-306.

99. Ding S, Qu W, Jiao Y, Zhang J, Zhang C, Dang S. LncRNA SNHG12 promotes the proliferation and metastasis of papillary thyroid carcinoma cells through regulating wnt/ $\beta$-catenin signaling pathway. Cancer Biomark. 2018;22(2):217-26

100. Liu X, Zheng J, Xue Y, Qu C, Chen J, Wang Z, et al. Inhibition of TDP43-mediated SNHG12-miR-195-SOX5 feedback loop impeded malignant biological behaviors of glioma cells. Mol Therapy-Nucleic Acids. 2018;10:142-58.

101. Zhou S, Yu L, Xiong M, Dai G. LncRNA SNHG12 promotes tumorigenesis and metastasis in osteosarcoma by upregulating Notch2 by sponging miR-195-5p. Biochem Biophys Res Commun. 2018;495(2):1822-32.

102. Zhang H, Lu W. LnCRNA SNHG12 regulates gastric cancer progression by acting as a molecular sponge of miR-320. Mol Med Rep. 2018;17(2):2743-9.

103. Zhou B, Li L, Li Y, Sun H, Zeng C. Long noncoding RNA SNHG12 mediates doxorubicin resistance of osteosarcoma via miR-320a/MCL1 axis. Biomed Pharmacother. 2018;106:850-7.

104. Wang L, Luo Y, Zheng Y, Zheng L, Lin W, Chen Z, et al. Long non-coding RNA LINC00426 contributes to doxorubicin resistance by sponging miR-4319 in osteosarcoma. Biol Direct. 2020;15(1):1-11.

105. Wang Z, Liu Z, Wu S. Long non-coding RNA CTA sensitizes osteosarcoma cells to doxorubicin through inhibition of autophagy. Oncotarget. 2017:8(19):31465.

106. Sharom FJ. ABC multidrug transporters: structure, function and role in chemoresistance. 2008.

107. Grote P, Wittler L, Hendrix D, Koch F, Währisch S, Beisaw A, et al. The tissue-specific IncRNA Fendrr is an essential regulator of heart and body wall development in the mouse. Dev Cell. 2013;24(2):206-14. 
108. Kun-Peng Z, Xiao-Long M, Chun-Lin Z. LncRNA FENDRR sensitizes doxorubicin-resistance of osteosarcoma cells through down-regulating ABCB1 and ABCC1. Oncotarget. 2017;8(42):71881.

109. Huang L, Wu R-L, Xu A-M. Epithelial-mesenchymal transition in gastric cancer. Am J TransI Res. 2015;7(11):2141

110. Li P, Xue W-J, Feng Y, Mao Q-S. Long non-coding RNA CASC2 suppresses the proliferation of gastric cancer cells by regulating the MAPK signaling pathway. Am J Transl Res. 2016;8(8):3522.

111. Kim BH, Hong SW, Kim A, Choi SH, Yoon SO. Prognostic implications for high expression of oncogenic microRNAs in advanced gastric carcinoma. J Surg Oncol. 2013;107(5):505-10.

112. Imaoka H, Toiyama Y, Okigami M, Yasuda H, Saigusa S, Ohi M, et al. Circulating microRNA-203 predicts metastases, early recurrence, and poor prognosis in human gastric cancer. Gastric Cancer. 2016;19(3):744-53.

113. Yang S-m, Huang C, Li X-f, Yu M-Z, He Y, Li J. miR-21 confers cisplatin resistance in gastric cancer cells by regulating PTEN. Toxicology. 2013;306:162-8.

114. Yuan C, Ning Y, Pan Y. Emerging roles of HOTAIR in human cancer. J Cell Biochem. 2020;121(5-6):3235-47.

115. Fang $\mathrm{S}$, Gao H, Tong Y, Yang J, Tang R, Niu Y, et al. Long noncoding RNA-HOTAIR affects chemoresistance by regulating HOXA1 methylation in small cell lung cancer cells. Lab Invest. 2016;96(1):60-8.

116. Wang $H$, Qin R, Guan A, Yao Y, Huang Y, Jia H, et al. HOTAIR enhanced paclitaxel and doxorubicin resistance in gastric cancer cells partly through inhibiting miR-217 expression. J Cell Biochem. 2018;1 19(9):7226-34.

117. Wang X-S, Zhang Z, Wang H-C, Cai J-L, Xu Q-W, Li M-Q, et al. Rapid identification of UCA1 as a very sensitive and specific unique marker for human bladder carcinoma. Clin Cancer Res. 2006;12(16):4851-8.

118. Fan Y, Shen B, Tan M, Mu X, Qin Y, Zhang F, et al. Long non-coding RNA UCA 1 increases chemoresistance of bladder cancer cells by regulating Wnt signaling. FEBS J. 2014;281(7):1750-8.

119. Jiang M, Huang $O$, Xie Z, Wu S, Zhang X, Shen A, et al. A novel long non-coding RNA-ARA: adriamycin resistance associated. Biochem Pharmacol. 2014:87(2):254-83.

120. Shang C, Guo Y, Zhang J, Huang B. Silence of long noncoding RNA UCA1 inhibits malignant proliferation and chemotherapy resistance to adriamycin in gastric cancer. Cancer Chemother Pharmacol. 2016;77(5):1061-7.

121. Geng Y, Lu X, Wu X, Xue L, Wang X, Xu J. MicroRNA-27b suppresses Helicobacter pylori-induced gastric tumorigenesis through negatively regulating Frizzled7. Oncol Rep. 2016;35(4):2441-50.

122. Liu H-T, Xing A-Y, Chen X, Ma R-R, Wang Y-W, Shi D-B, et al. MicroRNA-27b, microRNA-101 and microRNA-128 inhibit angiogenesis by down-regulating vascular endothelial growth factor $C$ expression in gastric cancers. Oncotarget. 2015;6(35):37458.

123. Fang $Q$, Chen X, Zhi X. Long non-coding RNA (LnCRNA) urothelial carcinoma associated 1 (UCA1) increases multi-drug resistance of gastric cancer via downregulating miR-27b. Med Sci Monitor: Int Med J Exp Clin Res. 2016;22:3506.

124. Yu H, Sun H, Bai Y, Han J, Liu G, Liu Y, et al. MEF2D overexpression contributes to the progression of osteosarcoma. Gene. 2015;563(2):130-5.

125. Canté-Barrett K, Pieters R, Meijerink J. Myocyte enhancer factor $2 \mathrm{C}$ in hematopoiesis and leukemia. Oncogene. 2014;33(4):403-10

126. Xu K, Zhao Y-C. MEF2D/Wnt/B-catenin pathway regulates the proliferation of gastric cancer cells and is regulated by microRNA-19. Tumor Biol. 2016;37(7):9059-69.

127. Liu L, Cui S, Zhang R, Shi Y, Luo L. MiR-421 inhibits the malignant phenotype in glioma by directly targeting MEF2D. Am J Cancer Res. 2017;7(4):857.

128. Zhou Z, Lin Z, He Y, Pang X, Wang Y, Ponnusamy M, et al. The long noncoding RNA D63785 regulates chemotherapy sensitivity in human gastric cancer by targeting miR-422a. Mol Therapy-Nucleic Acids. 2018;12:405-19.

129. Chen X, Kong J, Ma Z, Gao S, Feng X. Up regulation of the long non-coding RNA NEAT1 promotes esophageal squamous cell carcinoma cell progression and correlates with poor prognosis. Am J Cancer Res. 2015;5(9):2808.

130. Fu J-W, Kong Y, Sun X. Long noncoding RNA NEAT1 is an unfavorable prognostic factor and regulates migration and invasion in gastric cancer. J Cancer Res Clin Oncol. 2016;142(7):1571-9.

131. Zhang J, Zhao B, Chen X, Wang Z, Xu H, Huang B. Silence of long noncoding RNA NEAT1 inhibits malignant biological behaviors and chemotherapy resistance in gastric cancer. Pathol Oncol Res. 2018;24(1):109-13.

132. Wang Y, Zhang D, Wu K, Zhao Q, Nie Y, Fan D. Long noncoding RNA MRUL promotes ABCB1 expression in multidrug-resistant gastric cancer cell sublines. Mol Cell Biol. 2014;34(17):3182-93.

133. Konopleva M, Andreeff M. Targeting the leukemia microenvironment. Curr Drug Targets. 2007;8(6):685-701.

134. Sill H, Olipitz W, Zebisch A, Schulz E, Wölfler A. Therapy-related myeloid neoplasms: pathobiology and clinical characteristics. Br J Pharmacol. 2011;162(4):792-805.

135. Mini E, Lapucci A, Perrone G, D'Aurizio R, Napoli C, Brugia M, et al. RNA sequencing reveals PNN and KCNQ1 OT1 as predictive biomarkers of clinical outcome in stage III colorectal cancer patients treated with adjuvant chemotherapy. Int J Cancer. 2019;145(9):2580-93.

136. Zhang K, Yan J, Yi B, Rui Y, Hu H. High KCNQ1OT1 expression might independently predict shorter survival of colon adenocarcinoma. Future Oncol. 2019;15(10):1085-95.

137. Pandey RR, Mondal T, Mohammad F, Enroth S, Redrup L, Komorowski J, et al. Kcnq1ot1 antisense noncoding RNA mediates lineage-specific transcriptional silencing through chromatin-level regulation. Mol Cell. 2008;32(2):232-46.

138. Charrin S, Jouannet S, Boucheix C, Rubinstein E. Tetraspanins at a glance. J Cell Sci. 2014;127(17):3641-8.

139. Sun H, Sun Y, Chen Q, Xu Z. LncRNA KCNQ1OT1 contributes to the progression and chemoresistance in acute myeloid leukemia by modulating Tspan3 through suppressing miR-193a-3p. Life Sci. 2020;241:117161.

140. Cao R, Zhang Y. The functions of E (Z)/EZH2-mediated methylation of lysine 27 in histone H3. Curr Opin Genet Dev. 2004;14(2):155-64.

141. Li Q, Song W, Wang J. TUG1 confers Adriamycin resistance in acute myeloid leukemia by epigenetically suppressing miR-34a expression via EZH2. Biomed Pharmacother. 2019;109:1793-801.

142. Zhao H, Zhang X, Frazão JB, Condino-Neto A, Newburger PE. HOX antisense lincRNA HOXA-AS2 is an apoptosis repressor in all Trans retinoic acid treated NB4 promyelocytic leukemia cells. J Cell Biochem. 2013;1 14(10):2375-83. 
143. Lian Y, Li Z, Fan Y, Huang Q, Chen J, Liu W, et al. The IncRNA-HOXA-AS2/EZH2/LSD1 oncogene complex promotes cell proliferation in pancreatic cancer. Am J Transl Res. 2017;9(12):5496.

144. Dong X, Fang Z, Yu M, Zhang L, Xiao R, Li X, et al. Knockdown of long noncoding RNA HOXA-AS2 suppresses chemoresistance of acute myeloid leukemia via the miR-520c-3p/S100A4 axis. Cell Physiol Biochem. 2018;51(2):886-96.

145. Buitenhuis M, Coffer PJ. The role of the PI3K-PKB signaling module in regulation of hematopoiesis. Cell Cycle. 2009;8(4):560-6

146. Fruman DA, Rommel C. PI3K and cancer: lessons, challenges and opportunities. Nat Rev Drug Discovery. 2014;13(2):140-56

147. Yang Y, Dai W, Sun Y, Zhao Z. Long non-coding RNA linc00239 promotes malignant behaviors and chemoresistance against doxorubicin partially via activation of the PI3K/Akt/mTOR pathway in acute myeloid leukaemia cells. Oncol Rep. 2019;41(4):2311-20.

148. Ren R. Mechanisms of BCR-ABL in the pathogenesis of chronic myelogenous leukaemia. Nat Rev Cancer. 2005;5(3):172-83.

149. Mughal TI, Radich JP, Deininger MW, Apperley JF, Hughes TP, Harrison CJ, et al. Chronic myeloid leukemia: reminiscences and dreams. Haematologica. 2016;101(5):541-58.

150. Eechoute K, Sparreboom A, Burger H, Franke RM, Schiavon G, Verweij J, et al. Drug transporters and imatinib treatment: implications for clinical practice. Clin Cancer Res. 2011;17(3):406-15.

151. Peng X-X, Tiwari AK, Wu H-C, Chen Z-S. Overexpression of P-glycoprotein induces acquired resistance to imatinib in chronic myelogenous leukemia cells. Chin J Cancer. 2012;31(2):110.

152. Eadie L, Dang P, Saunders V, Yeung DT, Osborn MP, Grigg AP, et al. The clinical significance of ABCB1 overexpression in predicting outcome of CML patients undergoing first-line imatinib treatment. Leukemia. 2017:31(1):75-82.

153. Kapeli K, Yeo G. Genome-wide approaches to dissect the roles of RNA binding proteins in translational control: implications for neurological diseases. Front Neurosci. 2012;6:144.

154. Lebedeva S, Jens M, Theil K, Schwanhäusser B, Selbach M, Landthaler M, et al. Transcriptome-wide analysis of regulatory interactions of the RNA-binding protein HuR. Mol Cell. 2011;43(3):340-52.

155. Zhang F, Ni H, Li X, Liu H, Xi T, Zheng L. Lnc RNA FENDRR attenuates adriamycin resistance via suppressing MDR 1 expression through sponging HuR and miR-184 in chronic myelogenous leukaemia cells. FEBS Lett. 2019:593(15):1993-2007.

156. Jacobson C, LaCasce A. How I treat Burkitt lymphoma in adults. Blood. 2014;124(19):2913-20.

157. Kim H, Park ES, Lee SH, Koo HH, Kim HS, Lyu CJ, et al. Clinical outcome of relapsed or refractory Burkitt lymphoma and mature B-cell lymphoblastic leukemia in children and adolescents. Cancer Res Treatment: Off J Korean Cancer Assoc. 2014:46(4):358.

158. Siddiqui N, Sonenberg N. Signalling to elF4E in cancer. Biochem Soc Trans. 2015;43(5):763-72.

159. Hua H, Kong Q, Zhang H, Wang J, Luo T, Jiang Y. Targeting mTOR for cancer therapy. J Hematol Oncol. 2019;12(1):71.

160. Guo C, Gong M, Li Z. Knockdown of IncRNA MCM3AP-AS1 attenuates chemoresistance of burkitt lymphoma to doxorubicin treatment via targeting the miR-15a/EIF4E axis. Cancer Manag Res. 2020;12:5845.

161. Rahbari NN, Mehrabi A, Mollberg NM, Müller SA, Koch M, Büchler MW, et al. Hepatocellular carcinoma: current management and perspectives for the future. Ann Surg. 2011;253(3):453-69.

162. Osaki Y, Nishikawa H. Treatment for hepatocellular carcinoma in Japan over the last three decades: our experience and published work review. Hepatol Res. 2015;45(1):59-74.

163. Lu H, He Y, Lin L, Qi Z, Ma L, Li L, et al. Long non-coding RNA MALAT1 modulates radiosensitivity of HR-HPV+ cervical cancer via sponging miR-145. Tumor Biol. 2016;37(2):1683-91.

164. Tripathi V, Ellis JD, Shen Z, Song DY, Pan Q, Watt AT, et al. The nuclear-retained noncoding RNA MALAT1 regulates alternative splicing by modulating SR splicing factor phosphorylation. Mol Cell. 2010;39(6):925-38.

165. Ji Q, Liu X, Fu X, Zhang L, Sui H, Zhou L, et al. Resveratrol inhibits invasion and metastasis of colorectal cancer cells via MALAT1 mediated Wnt/B-catenin signal pathway. PLoS ONE. 2013;8(11):e78700.

166. Xu S, Sui S, Zhang J, Bai N, Shi Q, Zhang G, et al. Downregulation of long noncoding RNA MALAT1 induces epithelial-to-mesenchymal transition via the PI3K-AKT pathway in breast cancer. Int J Clin Exp Pathol. 2015;8(5):4881.

167. Wu X-S, Wang X-A, Wu W-G, Hu Y-P, Li M-L, Ding Q, et al. MALAT1 promotes the proliferation and metastasis of gallbladder cancer cells by activating the ERK/MAPK pathway. Cancer Biol Ther. 2014;15(6):806-14.

168. Ji D-G, Guan L-Y, Luo X, Ma F, Yang B, Liu H-Y. Inhibition of MALAT1 sensitizes liver cancer cells to 5 -flurouracil by regulating apoptosis through IKKa/NF-KB pathway. Biochem Biophys Res Commun. 2018;501(1):33-40.

169. Yuan P, Cao W, Zang Q, Li G, Guo X, Fan J. The HIF-2a-MALAT1-miR-216b axis regulates multi-drug resistance of hepatocellular carcinoma cells via modulating autophagy. Biochem Biophys Res Commun. 2016;478(3):1067-73.

170. Kim EK, Yoon SO, Jung WY, Lee H, Kang Y, Jang Y-J, et al. Implications of NOVA1 suppression within the microenvironment of gastric cancer: association with immune cell dysregulation. Gastric Cancer. 2017;20(3):438-47.

171. Li H, Lv B, Kong L, Xia J, Zhu M, Hu L, et al. Nova1 mediates resistance of rat pheochromocytoma cells to hypoxiainduced apoptosis via the Bax/Bcl-2/caspase-3 pathway. Int J Mol Med. 2017;40(4):1125-33.

172. Zhang Y-A, Liu H-N, Zhu J-M, Zhang D-Y, Shen X-Z, Liu T-T. RNA binding protein Nova1 promotes tumor growth in vivo and its potential mechanism as an oncogene may due to its interaction with GABA A Receptor- $\gamma 2$. J Biomed Sci. 2016;23(1):71.

173. Zhang Y-A, Zhu J-M, Yin J, Tang W-Q, Guo Y-M, Shen X-Z, et al. High expression of neuro-oncological ventral antigen 1 correlates with poor prognosis in hepatocellular carcinoma. PLoS ONE. 2014;9(3):e90955.

174. Cao Y, Zhang F, Wang H, Bi C, Cui J, Liu F, Pan H. LncRNA MALAT1 mediates doxorubicin resistance of hepatocellular carcinoma by regulating miR-3129-5p/Nova1 axis. Mol Cell Biochem. 2021;476(1):279-92.

175. Kessler SM, Hosseini K, Hussein UK, Kim KM, List M, Schultheiss CS, et al. Hepatocellular carcinoma and nuclear paraspeckles: induction in chemoresistance and prediction for poor survival. Cell Physiol Biochem. 2019;52(4):787-801 
176. Qu L, Ding J, Chen C, Wu Z-J, Liu B, Gao Y, et al. Exosome-transmitted IncARSR promotes sunitinib resistance in renal cancer by acting as a competing endogenous RNA. Cancer Cell. 2016;29(5):653-68.

177. Li Y, Ye Y, Feng B, Qi Y. Long noncoding RNA IncARSR promotes doxorubicin resistance in hepatocellular carcinoma via modulating PTEN-PI3K/Akt pathway. J Cell Biochem. 2017;118(12):4498-507.

178. Wang C, Ke S, Li M, Lin C, Liu X, Pan Q. Downregulation of LncRNA GAS5 promotes liver cancer proliferation and drug resistance by decreasing PTEN expression. Mol Genet Genomics. 2020;295(1):251-60.

179. Schultheiss CS, Laggai S, Czepukojc B, Hussein UK, List M, Barghash A, et al. The long non-coding RNA H19 suppresses carcinogenesis and chemoresistance in hepatocellular carcinoma. Cell Stress. 2017;1 (1):37-54.

180. Briggs SF, Pera RAR. X chromosome inactivation: recent advances and a look forward. Curr Opin Genet Dev. 2014;28:78-82.

181. Wang X, Zhang G, Cheng Z, Dai L, Jia L, Jing X, et al. Knockdown of LncRNA-XIST suppresses proliferation and TGF$\beta 1$-induced EMT in NSCLC through the notch-1 pathway by regulation of miR-137. Genet Test Mol Biomarkers. 2018;22(6):333-42.

182. Zhu J, Kong F, Xing L, Jin Z, Li Z. Prognostic and clinicopathological value of long noncoding RNA XIST in cancer. Clin Chim Acta. 2018:479:43-7.

183. Talarico C, Dattilo V, D'Antona L, Menniti M, Bianco C, Ortuso F, et al. SGK1, the new player in the game of resistance: chemo-radio molecular target and strategy for inhibition. Cell Physiol Biochem. 2016;39(5):1863-76.

184. Lang F, Perrotti N, Stournaras C. Colorectal carcinoma cells - regulation of survival and growth by SGK1. Int J Biochem Cell Biol. 2010;42(10):1571-5.

185. Amato R, Menniti M, Agosti V, Boito R, Costa N, Bond HM, et al. IL-2 signals through Sgk1 and inhibits proliferation and apoptosis in kidney cancer cells. J Mol Med. 2007;85(7):707-21.

186. Liang X, Lan C, Jiao G, Fu W, Long X, An Y, et al. Therapeutic inhibition of SGK1 suppresses colorectal cancer. Exp Mol Med. 2017;49(11):e399.

187. Zhu J, Zhang R, Yang D, Li J, Yan X, Jin K, et al. Knockdown of long non-coding RNA XIST inhibited doxorubicin resistance in colorectal cancer by upregulation of miR-124 and downregulation of SGK1. Cell Physiol Biochem. 2018;51(1):113-28.

188. Yu X, Zheng H, Chan MT, Wu WKK. BANCR: a cancer-related long non-coding RNA. Am J Cancer Res. 2017;7(9):1779.

189. Jiang M-C. CAS (CSE1L) signaling pathway in tumor progression and its potential as a biomarker and target for targeted therapy. Tumor Biol. 2016;37(10):13077-90.

190. Tai C-J, Hsu C-H, Shen S-C, Lee W-R, Jiang M-C. Cellular apoptosis susceptibility (CSE1L/CAS) protein in cancer metastasis and chemotherapeutic drug-induced apoptosis. J Exp Clin Cancer Res. 2010;29(1):110.

191. Ma S, Yang D, Liu Y, Wang Y, Lin T, Li Y, et al. LncRNA BANCR promotes tumorigenesis and enhances adriamycin resistance in colorectal cancer. Aging (Albany NY). 2018;10(8):2062.

192. Lu L-L, Chen X-H, Zhang G, Liu Z-C, Wu N, Wang H, et al. CCL21 facilitates chemoresistance and cancer stem cell-like properties of colorectal cancer cells through AKT/GSK-3ß/Snail signals. Oxidative Med Cell Longevity. 2016:2016.

193. Cioffi M, Trabulo SM, Sanchez-Ripoll Y, Miranda-Lorenzo I, Lonardo E, Dorado J, et al. The miR-17-92 cluster counteracts quiescence and chemoresistance in a distinct subpopulation of pancreatic cancer stem cells. Gut. 2015;64(12):1936-48.

194. Zhou X, Xiao D. Long non-coding RNA GAS5 is critical for maintaining stemness and induces chemoresistance in cancer stem-like cells derived from HCT116. Oncol Lett. 2020;19(5):3431-8.

195. Carling T, Udelsman R. Thyroid cancer. Annu Rev Med. 2014;65:125-37.

196. Haddad RI, Lydiatt WM, Ball DW, Busaidy NL, Byrd D, Callender G, et al. Anaplastic thyroid carcinoma, version 2.2015. J Natl Compr Cancer Netw. 2015;13(9):1140-50.

197. Zheng X, Cui D, Xu S, Brabant G, Derwahl M. Doxorubicin fails to eradicate cancer stem cells derived from anaplastic thyroid carcinoma cells: characterization of resistant cells. Int J Oncol. 2010;37(2):307-15.

198. Pawlus M, Wang L, Hu C. STAT3 and HIF1 a cooperatively activate HIF1 target genes in MDA-MB-231 and RCC4 cells. Oncogene. 2014;33(13):1670-9.

199. Yu H, Lee H, Herrmann A, Buettner R, Jove R. Revisiting STAT3 signalling in cancer: new and unexpected biological functions. Nat Rev Cancer. 2014;14(11):736-46.

200. Galoczova M, Coates P, Vojtesek B. STAT3, stem cells, cancer stem cells and p63. Cell Mol Biol Lett. 2018;23:12.

201. Conaway RC, Conaway JW. The INO80 chromatin remodeling complex in transcription, replication and repair. Trends Biochem Sci. 2009;34(2):71-7.

202. Xia S, Ji R, Zhan W. Long noncoding RNA papillary thyroid carcinoma susceptibility candidate 3 (PTCSC3) inhibits proliferation and invasion of glioma cells by suppressing the Wnt/ $\beta$-catenin signaling pathway. BMC Neurol. 2017:17(1):30.

203. Wang X-m, Liu Y, Fan Y-x, Liu Z, Yuan Q-I, Jia M, et al. LncRNA PTCSC3 affects drug resistance of anaplastic thyroid cancer through STAT3/INO80 pathway. Cancer Biol Therapy. 2018;19(7):590-7.

204. Wang Z, Shi X, Li Y, Fan J, Zeng X, Xian Z, et al. Blocking autophagy enhanced cytotoxicity induced by recombinant human arginase in triple-negative breast cancer cells. Cell Death Dis. 2014;5(12):e1563.

205. Cai Q, Wang S, Jin L, Weng M, Zhou D, Wang J, et al. Long non-coding RNA GBCDRInc1 induces chemoresistance of gallbladder cancer cells by activating autophagy. Mol Cancer. 2019;18(1):82.

206. Moritz LE, Trievel RC. Structure, mechanism, and regulation of polycomb-repressive complex 2. J Biol Chem. 2018;293(36):13805-14.

207. Liu L, Xu Z, Zhong L, Wang H, Jiang S, Long Q, et al. Enhancer of zeste homolog 2 (EZH2) promotes tumour cell migration and invasion via epigenetic repression of E-cadherin in renal cell carcinoma. BJU Int. 2016;117(2):351-62.

208. Duan J, Ma X, Shi J, Xuan Y, Wang H, Li P, et al. Long noncoding RNA LINC-PINT promotes proliferation through EZH2 and predicts poor prognosis in clear cell renal cell carcinoma. Onco Targets Ther. 2019;12:4729. 
209. Hu L, Ye H, Huang G, Luo F, Liu Y, Liu Y, et al. Long noncoding RNA GAS5 suppresses the migration and invasion of hepatocellular carcinoma cells via miR-21. Tumor Biol. 2016;37(2):2691-702.

210. Gao J, Liu M, Zou Y, Mao M, Shen T, Zhang C, et al. Long non-coding RNA growth arrest-specific transcript 5 is involved in ovarian cancer cell apoptosis through the mitochondria-mediated apoptosis pathway. Oncol Rep. 2015;34(6):3212-21.

211. Guo X, Deng K, Wang H, Xia J, Shan T, Liang Z, et al. GAS5 inhibits gastric cancer cell proliferation partly by modulating CDK6. Oncol Res Treatment. 2015;38(7-8):362-6.

212. Zhang H, Guo Y, Song Y, Shang C. Long noncoding RNA GAS5 inhibits malignant proliferation and chemotherapy resistance to doxorubicin in bladder transitional cell carcinoma. Cancer Chemother Pharmacol. 2017;79(1):49-55.

213. Shang C, Guo Y, Zhang H, Xue Y-X. Long noncoding RNA HOTAIR is a prognostic biomarker and inhibits chemosensitivity to doxorubicin in bladder transitional cell carcinoma. Cancer Chemother Pharmacol. 2016:77(3):507-13.

214. Kagan HM, Li W. Lysyl oxidase: properties, specificity, and biological roles inside and outside of the cell. J Cell Biochem. 2003:88(4):660-72

215. Long B, Li N, Xu X-X, Li X-X, X X X-J, Liu J-Y, et al. Long noncoding RNA LOXL1-AS1 regulates prostate cancer cell proliferation and cell cycle progression through miR-541-3p and CCND1. Biochem Biophys Res Commun. 2018;505(2):561-8.

216. Delaney C, Frank S, Huang RS. Pharmacogenomics of EGFR-targeted therapies in non-small cell lung cancer: EGFR and beyond. Chin J Cancer. 2015;34(3):7.

217. Abbaszadegan MR, Riahi A, Forghanifard MM, Moghbeli M. WNT and NOTCH signaling pathways as activators for epidermal growth factor receptor in esophageal squamous cell carcinoma. Cell Mol Biol Lett. 2018;23:42.

218. Hynes NE, Lane HA. ERBB receptors and cancer: the complexity of targeted inhibitors. Nat Rev Cancer. 2005:5(5):341-54.

219. Bai T, Liu Y, Li B. LnCRNA LOXL1-AS1/miR-let-7a-5p/EGFR-related pathway regulates the doxorubicin resistance of prostate cancer DU-145 cells. IUBMB Life. 2019;71(10):1537-51.

\section{Publisher's Note}

Springer Nature remains neutral with regard to jurisdictional claims in published maps and institutional affiliations.

- fast, convenient online submission

- thorough peer review by experienced researchers in your field

- rapid publication on acceptance

- support for research data, including large and complex data types

- gold Open Access which fosters wider collaboration and increased citations

- maximum visibility for your research: over $100 \mathrm{M}$ website views per year

At BMC, research is always in progress.

Learn more biomedcentral.com/submissions 